\title{
Photoperiod-induced clock-shifting in the circadian protein and amino acid rhythms in the larval fat body of silkworm, Bombyx mori
}

\author{
B. Sailaja and S. Sivaprasad* \\ Department of Zoology, Smt. N.P.S. Government College for Women, Chittoor-517 002 (A.P), INDIA \\ *Corresponding author. E-mail: sivaprasadzoology@yahoo.co.in
}

Abstract: The photoperiod-induced clock-shifting in the free running time of the circadian protein and amino acid rhythms was studied in the larval fat body of Bombyx mori. The analysis of peaks and troughs of phase response curves of the rhythm revealed that the fourth and fifth instar larvae grown under normal $12 \mathrm{~h}$ light and $12 \mathrm{~h}$ dark cycle (LD) showed 7 protein synthetic cycles, while those reared under continuous light (LL) recorded 9.5 cycles in fourth instar and 8 in fifth instar. Under continuous dark (DD), the protein rhythm maintained 8 cycles in fourth instar and 7.5 cycles in fifth instar. Clearly, both LL and DD conditions advance the 24-h free running time of the protein rhythm by durations ranging from 1.6 to $6.5 \mathrm{~h}$. Comparative analysis of protein and amino acid rhythms shows that the photoperiod modulates the free running time of the former by altering the rate of amino acid mobilization.

Keywords: Bombyx mori, Circadian amino acid rhythm, Circadian protein rhythm, Fat body, Photoperiod

\section{INTRODUCTION}

Like the mammalian liver, insect fat body is a dynamic metabolic tissue that performs multiple physiological functions in energy and intermediary metabolisms (Scott et al., 2004; Arrese and Soulages, 2010). Its constituent cells; trophocytes, urocytes and mycetocytes play unique roles in metabolism (Pajio, 2010). While the trophocytes synthesize and store the biochemical constituents of carbohydrate, protein and lipid metabolisms, the mycetocytes facilitate vitamin B synthesis and symbiotic cellulose digestion and urocytes help in storage-excretion of uric acid (David and Ananthakrishnan, 2006). The proteomic analysis of the fat body in Bombyx mori revealed the presence of 722 proteins involved in larval growth, development and metamorphosis that are synthesized and released at regular intervals (Hou et al., 2007). Moreover, the insect fat body is known to contain endogenous pacemakers that modulate locomotory and feeding behaviours (Kanyan Xu et al., 2008) probably by causing rhythmic changes in its biochemical profiles including proteins. Evidently, the fat body protein levels are subjected to rhythmic changes under the influence of light-sensitive endogenous circadian clock mechanism.

The economically important insect Bombyx mori has been viewed as a powerful model for the study of circadian rhythms next only to D rosophila. Most of the circadian studies focused on the identification, isolation and cloning of silk genes (Ishikawa and Suzuki, 1985; Kimura et al., 1985; Obara and Suzuki, 1988; Michaille et al., 1989; Durand et al., 1992; Fukuta, et al., 1993; Gizelak, 1995), determination of their expression patterns and identification of their products (Hall, 2003; Sharma, 2003; Iwai et al., 2006) and the identification of tissue-specific endogenous pace makers or circadian clocks (Sehadova et al., 2004; Reppert, 2006; Dolezel etal., 2008). Obviously, these studies attempted to elucidate the molecular and genetic mechanisms without taking into cognizance its impact on the tissue-specific biochemical profiles. In order to bridge this gap, we made an attempt to analyze circadian changes in the fat body protein and amino acid profiles in the silkworm larvae during the fourth and fifth instars under the influence of altered photoperiodic conditions with a view to ascertain instar-specific and photoperiodic-specific clock-shifting in the free running time of the circadian protein rhythm.

\section{MATERIALS AND METHODS}

The present study was carried out on the Pure Mysore $\mathrm{x}$ $\mathrm{CSR}_{2}$ hybrid variety of the silkworm Bombyx mori, reared under standard environmental conditions of $28^{\circ} \mathrm{C}, 85 \%$ RH, as per Krishnaswamy (1986). After hatching from the eggs, the larvae were reared on $\mathrm{M}_{5}$ variety of mulberry laves five times a day, at 6AM, $10 \mathrm{AM}, 2 \mathrm{PM}, 6 \mathrm{PM}$ and $10 \mathrm{PM}$ under $12 \mathrm{~h}$ light and $12 \mathrm{~h}$ dark cycle. After the third moult, the larvae were divided into three batches, reared and fed separately under three different photoperiodic conditions, viz., $12 \mathrm{~h}$ light and $12 \mathrm{~h}$ dark cycle (LD), continuous light (LL) and continuous dark (DD) throughout the development of the fourth and fifth larval instars. 
The fat body tissue was isolated every hour by dissecting the silkworm larvae in ice-cold Silkworm Ringer (Yamaoka et al., 1971). The circadian changes in the levels of total and soluble proteins was analyzed in $1 \%$ tissue homogenates in distilled water by the method of Lowry et al. (1951) on hourly basis from $8 \mathrm{~A}$. M onwards for a period of $25 \mathrm{~h}$ that spans in between $3^{\text {rd }}$ and $4^{\text {th }}$ day of fourth instar and $5^{\text {th }}$ and $6^{\text {th }}$ day of fifth instar. The rhythmic changes in the levels of structural proteins were obtained by subtracting the levels of soluble proteins from total proteins. The circadian changes in the levels of amino acids were assayed on bi-hourly basis by the method of Moore and Stein (1954) as described by Colowick and Kaplan (1957) in 10\% homogenates of the tissue in 10\% TCA, during the same period.

\section{RESULTS}

The 24-h changes in the protein and amino acid rhythms is designated the free running period or tau and shown in the form of phase response curves with its characteristic peaks (elevated points) and troughs (low points) in figures 1 to 6 . The circadian data was analyzed in terms of intervals between peaks and troughs and presented in tables 1 to 5 . The protein and amino acid levels were expressed in $\mathrm{mg} / \mathrm{g}$ wet weight of tissue. Fourth instar larval rhythms

Total proteins: Under 12:12 light: dark cycle (LD), the free running time of the total protein rhythm of the fat body showed 6 peaks and 6 troughs (Fig. 1A; Tables 1 and 2). The peaks occurred at $11 \mathrm{~h}(\sim 70 \mathrm{mg} / \mathrm{g}$ wet wt. of tissue), $13 \mathrm{~h}(\sim 64 \mathrm{mg}) 17 \mathrm{~h}(\sim 76 \mathrm{mg}), 22 \mathrm{~h}(64 \mathrm{mg})$ and next day at $04 \mathrm{~h}(\sim 59 \mathrm{mg})$ and $07 \mathrm{~h}(\sim 55 \mathrm{mg})$. Similarly, troughs appeared at $08 \mathrm{~h}(\sim 49 \mathrm{mg}), 12 \mathrm{~h}(\sim 50 \mathrm{mg}), 15 \mathrm{~h}(\sim 46 \mathrm{mg})$, $20 \mathrm{~h}(\sim 38 \mathrm{mg})$ and next day at $02 \mathrm{~h}(\sim 37 \mathrm{mg})$ and $06 \mathrm{~h}(\sim 45$ $\mathrm{mg}$ ). Under continuous light (LL), 10 peaks and 9 troughs were recorded in the tau of the total protein rhythm. Peaks in the protein levels were recorded at $8 \mathrm{~h}(\sim 40 \mathrm{mg}), 11 \mathrm{~h}$ $(\sim 52 \mathrm{mg}), 13 \mathrm{~h}$ ( $\sim 54 \mathrm{mg}), 15 \mathrm{~h}(\sim 47 \mathrm{mg}), 17 \mathrm{~h}(\sim 46 \mathrm{mg}), 22$ $\mathrm{h}(52 \mathrm{mg}), 00 \mathrm{~h}(\sim 49 \mathrm{mg})$ and next day at $02 \mathrm{~h}(\sim 54 \mathrm{mg}), 04$ $\mathrm{h}(\sim 48 \mathrm{mg})$ and $08 \mathrm{~h}(\sim 38 \mathrm{mg})$. Similarly, under LL, troughs were recorded at $09 \mathrm{~h}(\sim 26 \mathrm{mg}), 12 \mathrm{~h}(43 \mathrm{mg}), 14 \mathrm{~h}(\sim 45$ $\mathrm{mg}), 16 \mathrm{~h}(\sim 45 \mathrm{mg}), 18 \mathrm{~h}(\sim 37 \mathrm{mg}), 23 \mathrm{~h}(\sim 40 \mathrm{mg})$ and next day at $01 \mathrm{~h}(\sim 44 \mathrm{mg}), 03 \mathrm{~h}(\sim 42 \mathrm{mg})$ and $06 \mathrm{~h}(\sim 30 \mathrm{mg})$. Under continuous dark (DD) the total protein content of the fat body recorded 8 peaks and 8 troughs during the $24 \mathrm{~h}$ free running period of the rhythm. Peaks occurred at $08 \mathrm{~h}(\sim 44 \mathrm{mg}), 11 \mathrm{~h}(\sim 52 \mathrm{mg}), 15 \mathrm{~h}(\sim 51 \mathrm{mg}), 20 \mathrm{~h}(\sim 53$ $\mathrm{mg}), 23 \mathrm{~h}(\sim 42 \mathrm{mg})$ and next day at $01 \mathrm{~h}(\sim 47 \mathrm{mg}), 05 \mathrm{~h}$ $(\sim 50 \mathrm{mg})$ and $07 \mathrm{~h}(\sim 50 \mathrm{mg})$. Likewise, under DD, troughs appeared at $09 \mathrm{~h}(\sim 36 \mathrm{mg}), 14 \mathrm{~h}(\sim 43 \mathrm{mg}), 16 \mathrm{~h}(42 \mathrm{mg}), 18$ $\mathrm{h}(\sim 38 \mathrm{mg}), 22 \mathrm{~h}(\sim 35 \mathrm{mg})$ and next day at $02 \mathrm{~h}(\sim 17 \mathrm{mg})$, $06 \mathrm{~h}(\sim 45 \mathrm{mg})$ and $08 \mathrm{~h}(\sim 48 \mathrm{mg})$. Though, the individual intervals between any two peaks or troughs ranged from 2 to $6 \mathrm{~h}$, the mean interval between any two peaks or troughs stood at $3.5 \mathrm{~h}$ under LD, 2.4 h under LL and 2.9 under DD (Fig. 1 A; Tables 1 and 2).

Soluble proteins: Under LD, the 24-h tau of the soluble protein rhythm showed 7 peaks and 8 troughs (Fig. 1B; Tables 1 and 2). Peaks appeared at $11 \mathrm{~h}(\sim 59 \mathrm{mg}), 3 \mathrm{~h}(\sim 54$ $\mathrm{mg}), 18 \mathrm{~h}(\sim 47 \mathrm{mg}), 21 \mathrm{~h}(\sim 35 \mathrm{mg}), 00 \mathrm{~h}(\sim 35 \mathrm{mg})$ and next day at $04 \mathrm{~h}(\sim 37 \mathrm{mg})$ and $06 \mathrm{~h}(\sim 36 \mathrm{mg})$. Troughs occurred at $08 \mathrm{~h}(31 \mathrm{mg}), 12 \mathrm{~h}(\sim 32 \mathrm{mg}), 15 \mathrm{~h}(\sim 39 \mathrm{mg}), 20 \mathrm{~h}(\sim 20$ $\mathrm{mg}), 22 \mathrm{~h}(\sim 15 \mathrm{mg})$ and next day at $02 \mathrm{~h}(\sim 13 \mathrm{mg}), 05 \mathrm{~h}$ $(\sim 16 \mathrm{mg})$ and $08 \mathrm{~h}(\sim 29 \mathrm{mg})$. Under LL, the $24-\mathrm{h}$ free running time of the soluble protein rhythm recorded 10 peaks and 9 troughs. Peaks in soluble protein levels occurred at $08 \mathrm{~h}(\sim 39 \mathrm{mg}), 11 \mathrm{~h}(\sim 38 \mathrm{mg}), 13 \mathrm{~h}(\sim 41 \mathrm{mg})$, $15 \mathrm{~h}(\sim 41 \mathrm{mg}), 17 \mathrm{~h}(\sim 37 \mathrm{mg}), 20 \mathrm{~h}(\sim 36 \mathrm{mg}), 22 \mathrm{~h}(35 \mathrm{mg})$, $00 \mathrm{~h}(\sim 35 \mathrm{mg})$ and next day at 02-03-04 h ( $\sim 35 \mathrm{mg}$ each $)$ and $08 \mathrm{~h}(\sim 28 \mathrm{mg})$. Similarly, troughs in their levels appeared at $09 \mathrm{~h}(\sim 15 \mathrm{mg}), 12 \mathrm{~h}(\sim 33 \mathrm{mg}), 14 \mathrm{~h}(\sim 32 \mathrm{mg})$, $16 \mathrm{~h}$ ( $\sim 32 \mathrm{mg}), 18-19 \mathrm{~h}$ ( $\sim 34 \mathrm{mg}$ each $), 21 \mathrm{~h}(\sim 30 \mathrm{mg}), 23 \mathrm{~h}$ $(\sim 33 \mathrm{mg})$ and next day at $01 \mathrm{~h}(\sim 31 \mathrm{mg})$ and at $07 \mathrm{~h}(\sim 22$ $\mathrm{mg}$ ). Under DD, the 24 -h free running time of the soluble protein rhythm recorded 9 peaks and 9 troughs. Peaks appeared at $09 \mathrm{~h}(\sim 34 \mathrm{mg}), 11 \mathrm{~h}(\sim 43 \mathrm{mg}), 13 \mathrm{~h}(\sim 39 \mathrm{mg})$, $15 \mathrm{~h}(\sim 33 \mathrm{mg}), 17 \mathrm{~h}(\sim 33 \mathrm{mg}), 19 \mathrm{~h}(\sim 32 \mathrm{mg}), 22-23 \mathrm{~h}(\sim 31$ $\mathrm{mg}$ each $)$ and next day at $05 \mathrm{~h}(\sim 31 \mathrm{mg})$ and $08 \mathrm{~h}(\sim 31$ $\mathrm{mg})$. Similarly, troughs occurred at $08 \mathrm{~h}(\sim 32 \mathrm{mg}), 10 \mathrm{~h}(\sim$ $30 \mathrm{mg}), 12 \mathrm{~h}(\sim 33 \mathrm{mg}), 14 \mathrm{~h}(\sim 30 \mathrm{mg}), 16 \mathrm{~h}(\sim 30 \mathrm{mg}), 18 \mathrm{~h}$ $(\sim 28 \mathrm{mg}), 21 \mathrm{~h}(\sim 26 \mathrm{mg})$ and next day at $02 \mathrm{~h}(\sim 7 \mathrm{mg})$ and $06 \mathrm{~h}(\sim 26 \mathrm{mg})$. While the individual intervals between any two peaks or any two troughs ranged from 2 to $6 \mathrm{~h}$, their combined mean interval stood at $\sim 2.9 \mathrm{~h}$ under $\mathrm{LD}$, $\sim 2.3 \mathrm{~h}$ under LL and $\sim 2.6$ under DD (Fig. 1B; Tables 1 and 2).

Structural proteins: Under LD, the 24-h free running time of the structural protein rhythm showed 8 peaks and 8 troughs (Fig. 1C; Tables 1 and 2). Peaks appeared at $08 \mathrm{~h}(\sim 15 \mathrm{mg}), 12 \mathrm{~h}(\sim 17 \mathrm{mg}), 17 \mathrm{~h}(\sim 30 \mathrm{mg}), 20 \mathrm{~h}(\sim 18$ $\mathrm{mg}), 22 \mathrm{~h}(\sim 49 \mathrm{mg})$ and next day at $01 \mathrm{~h}(\sim 27 \mathrm{mg}) 05 \mathrm{~h}(\sim 35$ $\mathrm{mg})$ and $07 \mathrm{~h}(\sim 20 \mathrm{mg})$. Similarly, troughs were observed at $09-10 \mathrm{~h}(\sim 9 \mathrm{mg}$ each $), 15 \mathrm{~h}(\sim 7.5 \mathrm{mg}), 18 \mathrm{~h}(\sim 5.2 \mathrm{mg}), 21$ $\mathrm{h}(\sim 7 \mathrm{mg}), 00 \mathrm{~h}(\sim 16 \mathrm{mg})$ and next day at $03 \mathrm{~h}(\sim 15 \mathrm{mg}), 06$ $\mathrm{h}(\sim 9 \mathrm{mg})$ and $08 \mathrm{~h}(\sim 13 \mathrm{mg})$. Under LL, the structural protein rhythm recorded 9 peaks and 9 troughs. Peaks occurred at $09 \mathrm{~h}(\sim 11 \mathrm{mg}), 11 \mathrm{~h}(\sim 15 \mathrm{mg}), 13 \mathrm{~h}(\sim 13 \mathrm{mg})$, $16 \mathrm{~h}(\sim 14 \mathrm{mg}), 21 \mathrm{~h}(\sim 19 \mathrm{mg}), 00 \mathrm{~h}(\sim 14 \mathrm{mg})$ and next day again at $02 \mathrm{~h}(\sim 19 \mathrm{mg}), 04 \mathrm{~h}(\sim 11 \mathrm{mg})$ and $07 \mathrm{~h}(\sim 9 \mathrm{mg})$. At the same time troughs were recorded at $08 \mathrm{~h}(\sim 10 \mathrm{mg}), 10$ $\mathrm{h}(\sim 10 \mathrm{mg}), 12 \mathrm{~h}(\sim 9.8 \mathrm{mg}), 15 \mathrm{~h}(\sim 6 \mathrm{mg}), 18 \mathrm{~h}(\sim 4 \mathrm{mg}), 23$ $\mathrm{h}(\sim 7 \mathrm{mg})$ and again next day at $01 \mathrm{~h}(\sim 12 \mathrm{mg}), 03 \mathrm{~h}(\sim 7$ $\mathrm{mg})$ and $06 \mathrm{~h}(\sim 4 \mathrm{mg})$. Under DD, the structural protein rhythm recorded 8 peaks and 8 troughs during the 24-h free running time. Peaks appeared at $08 \mathrm{~h}(\sim 12 \mathrm{mg}), 12 \mathrm{~h}$ $(\sim 17 \mathrm{mg}), 15 \mathrm{~h}(\sim 18 \mathrm{mg}), 20 \mathrm{~h}(\sim 23 \mathrm{mg}), 23 \mathrm{~h}(11 \mathrm{mg})$ and next day again at $01 \mathrm{~h}(\sim 16 \mathrm{mg}), 04 \mathrm{~h}(\sim 23 \mathrm{mg})$ and $07 \mathrm{~h}$ $(\sim 19 \mathrm{mg})$. Similarly, troughs occurred at $09 \mathrm{~h}(\sim 2 \mathrm{mg}), 13 \mathrm{~h}$ $(\sim 6 \mathrm{mg}), 17 \mathrm{~h}(\sim 6.5 \mathrm{mg}), 22 \mathrm{~h}(4.6 \mathrm{mg}), 00 \mathrm{~h}(\sim 10 \mathrm{mg})$ and 


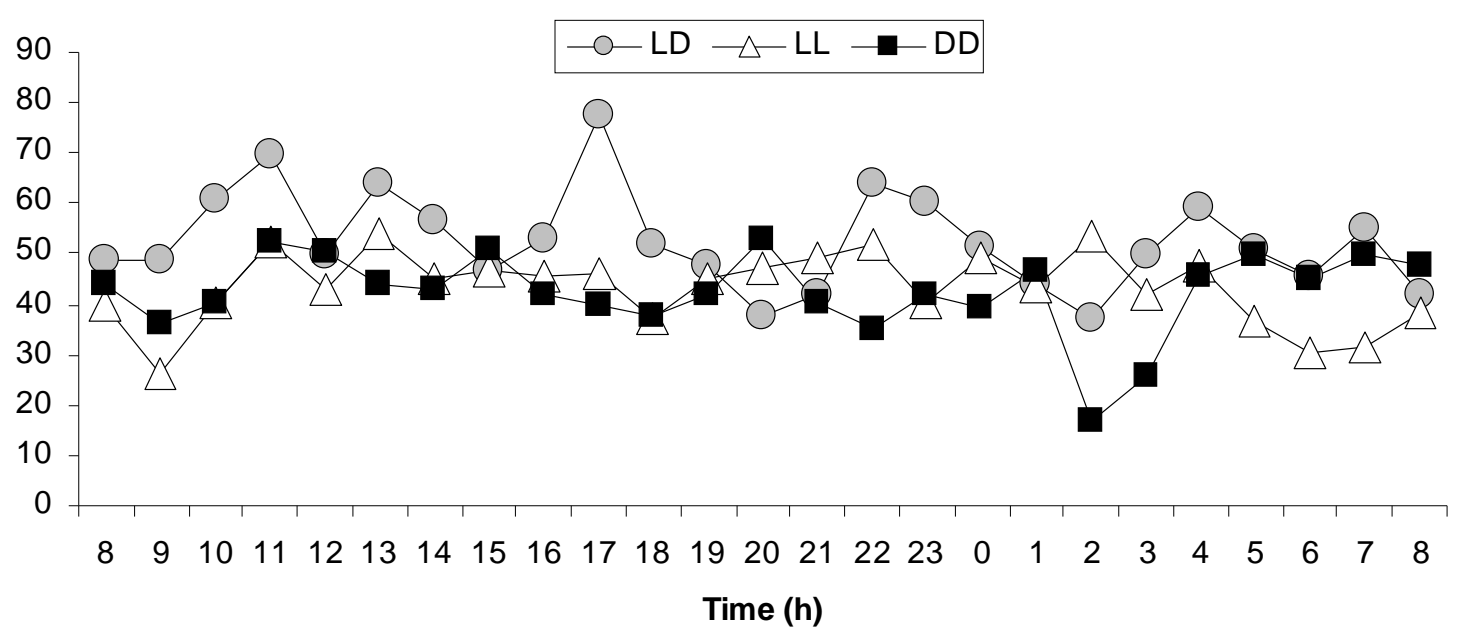

(A). Fat body total protein rhythm in IV instar (mg/g).

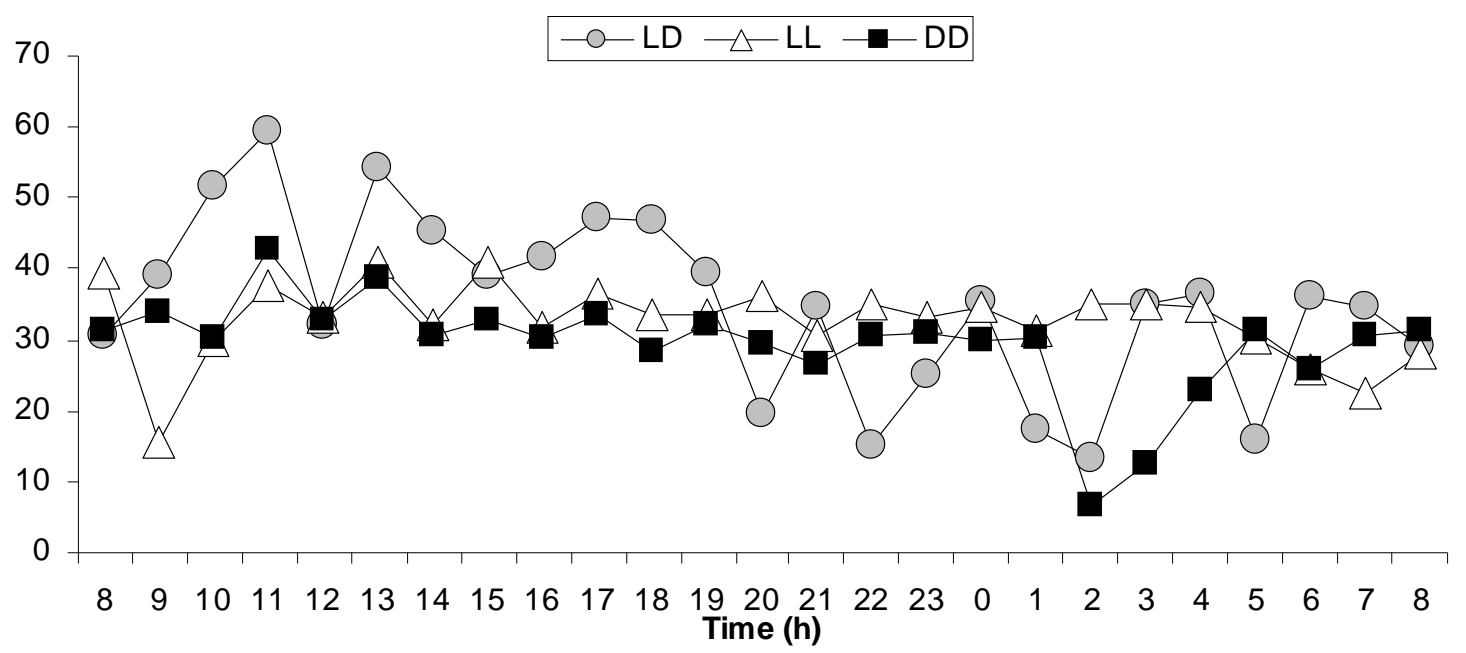

(B). Fat body soluble protein rhythm in IV instar $(\mathrm{mg} / \mathrm{g})$

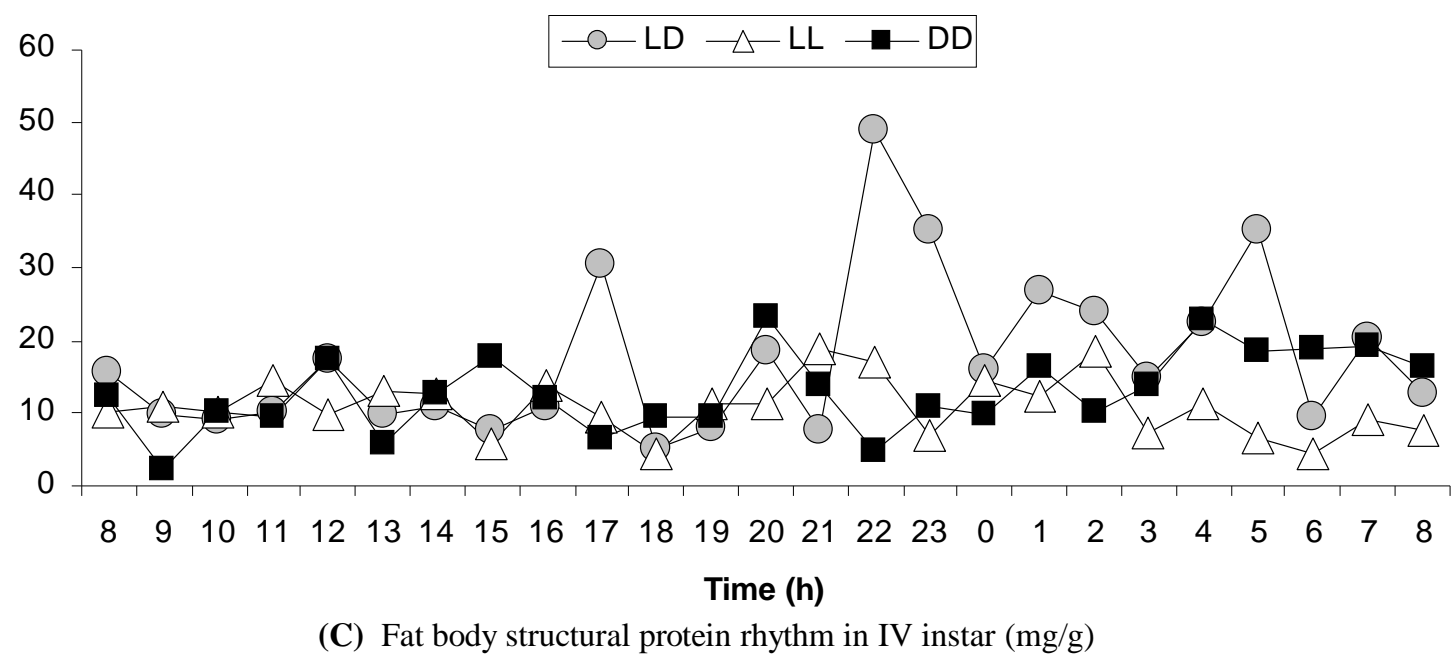

Fig. 1. Phase response curves (PRCs) of the 24 -h circadian protein rhythms (from $8 A M$ on day 3 to $8 A M$ on day 4 ) in the fat body of the fourth instar larva of Bombyx mori, under $12 \mathrm{~h}$ light: $12 \mathrm{~h}$ dark cycle (LD); continuous light (LL) and continuous dark (DD ).A. Total proteins; B. soluble proteins and C. structural proteins. (P values: $<0.001$ ).

next day at $02 \mathrm{~h}(10 \mathrm{mg}), 05 \mathrm{~h}(\sim 18 \mathrm{mg})$ and $08 \mathrm{~h}(\sim 16 \mathrm{mg})$.

The individual intervals between any two peaks or troughs ranged from 2 to $6 \mathrm{~h}$, their mean interval was $\sim 2.9 \mathrm{~h}$ under $\mathrm{LD}, \sim 2.6 \mathrm{~h}$ under LL and $2.9 \mathrm{~h}$ under DD
(Fig. 1C; Tables 1 and 2).

Freeamino acids: In the fourth instar larva, the free amino acid rhythm of the fat body maintained relatively higher levels under LL and DD conditions compared to LD (Fig. 


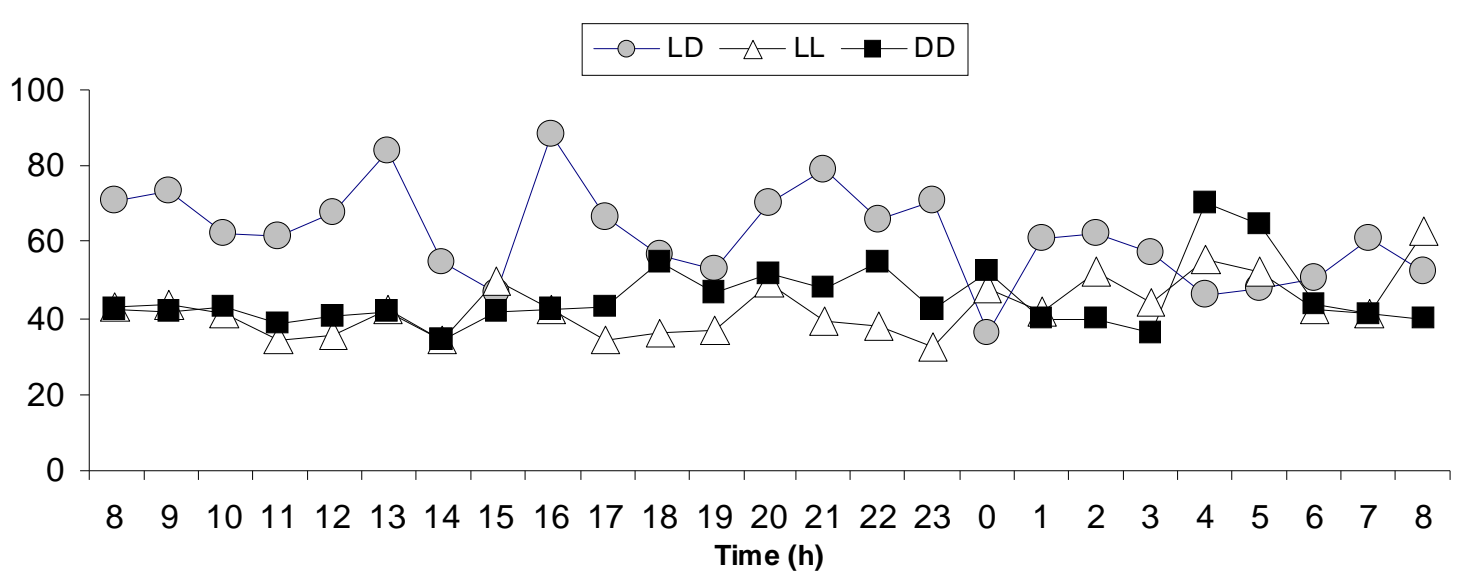

(A). Fat body total protein rhythum in $\mathrm{V}$ instar $(\mathrm{mg} / \mathrm{g})$

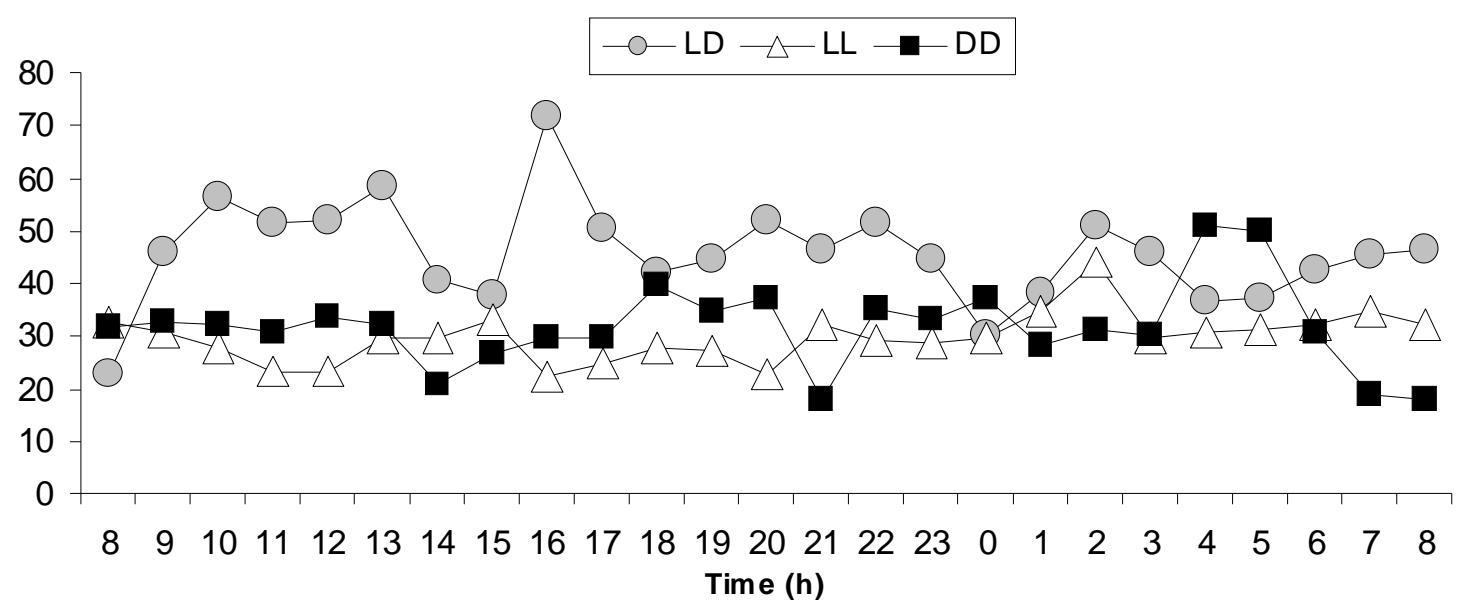

(B). Fat body soluble protein rhythum in $\mathrm{V}$ instar $(\mathrm{mg} / \mathrm{g})$

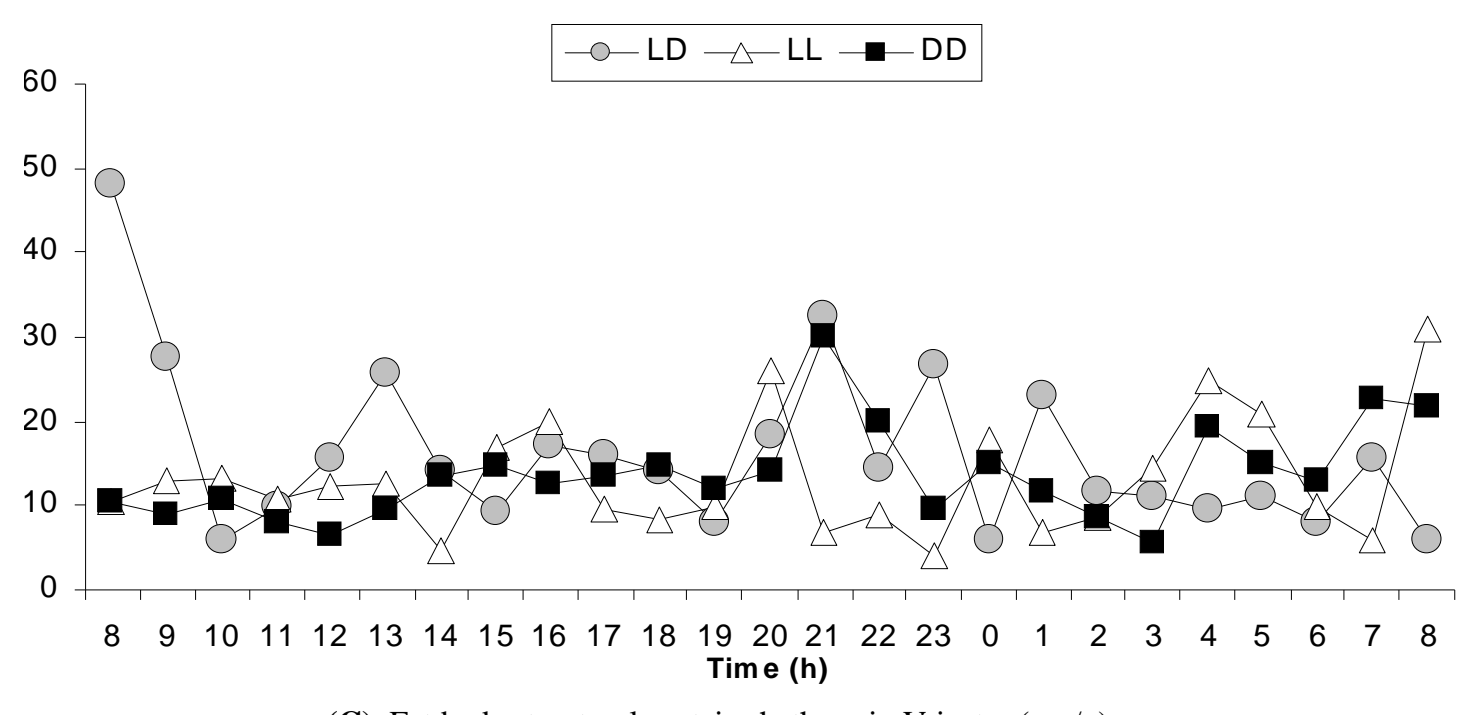

(C). Fat body structural protein rhythum in $\mathrm{V}$ instar $(\mathrm{mg} / \mathrm{g})$

Fig. 2. Phase response curves (PRC) of the 24-h circadian protein rhythm ( from $8 \mathrm{AM}$ on day 5 to $8 \mathrm{AM}$ on day 6 ) in the fat body of fifth instar larva of Bombyx mori, under $12 \mathrm{~h} \mathrm{light:} 12 \mathrm{~h}$ dark cycle (LD); continuous light (LL) and continuous dark (DD) conditions. A. Total proteins; B. soluble proteins and C. structural proteins. (P values: <0.001).

$3 \mathrm{~A})$. Under $\mathrm{LD}$, their levels ranged from $\sim 6 \mathrm{mg}$ to $\sim 22 \mathrm{mg}$ during the free running time, showing peaks at $08 \mathrm{~h}(8.7$ $\mathrm{mg}), 20 \mathrm{~h}(\sim 15 \mathrm{mg})$ and next day at $2 \mathrm{~h}(\sim 22 \mathrm{mg})$. Similarly, troughs in their levels were recorded at $12 \mathrm{~h}(\sim 6 \mathrm{mg}), 22 \mathrm{~h}$ $(\sim 9 \mathrm{mg})$ on day-1, and again next day at $06 \mathrm{~h}(\sim 7 \mathrm{mg})$.
Under LL, significantly a higher rhythm $(\sim 15$ to $\sim 38 \mathrm{mg})$ is maintained in their levels, with peaks at $12 \mathrm{~h}(\sim 38 \mathrm{mg})$ $20 \mathrm{~h}(\sim 38 \mathrm{mg})$ and again next day at $8 \mathrm{~h}(\sim 26 \mathrm{mg})$. Similarly, troughs in free amino acid levels were observed at $14 \mathrm{~h}$ $(\sim 28 \mathrm{mg}), 00 \mathrm{~h}(\sim 29 \mathrm{mg})$ and again, next day at $06 \mathrm{~h}(\sim 15$ 


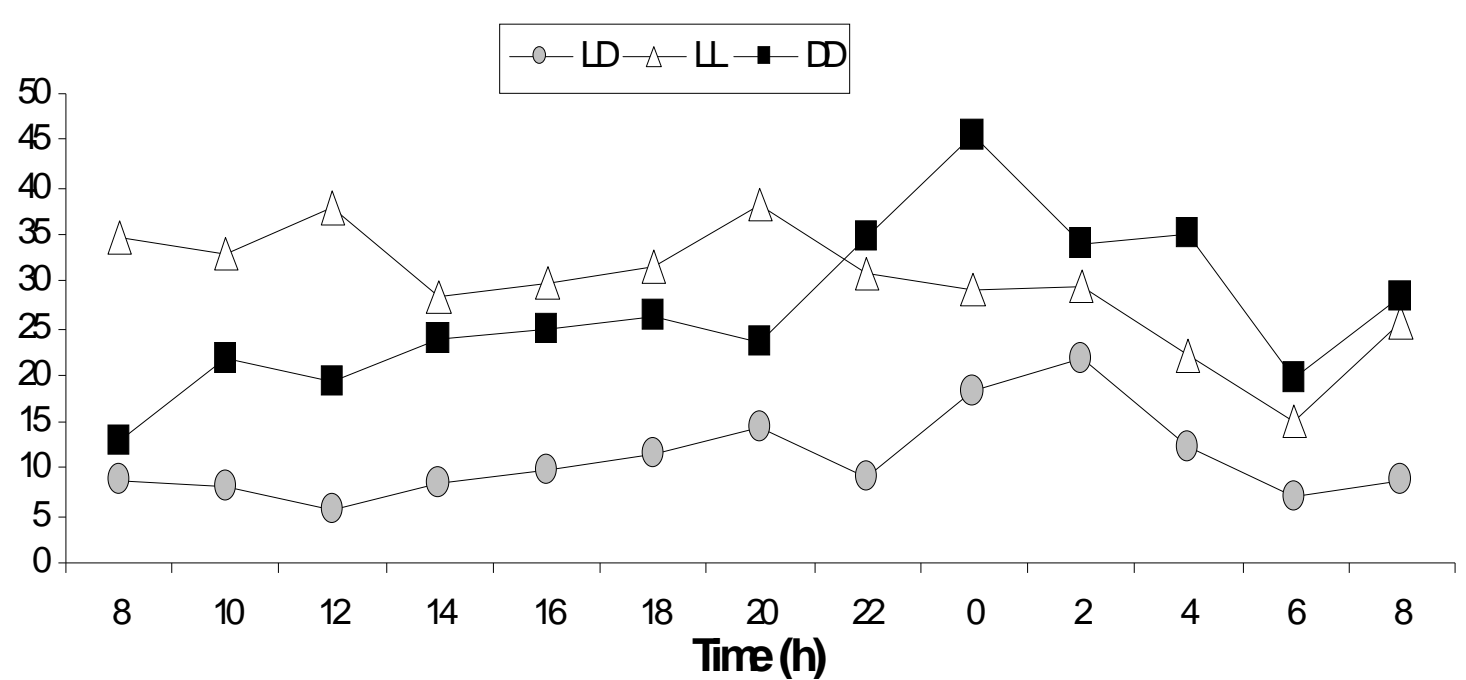

(A). Fat body amino acid rhythm-IV instar (mg/g)

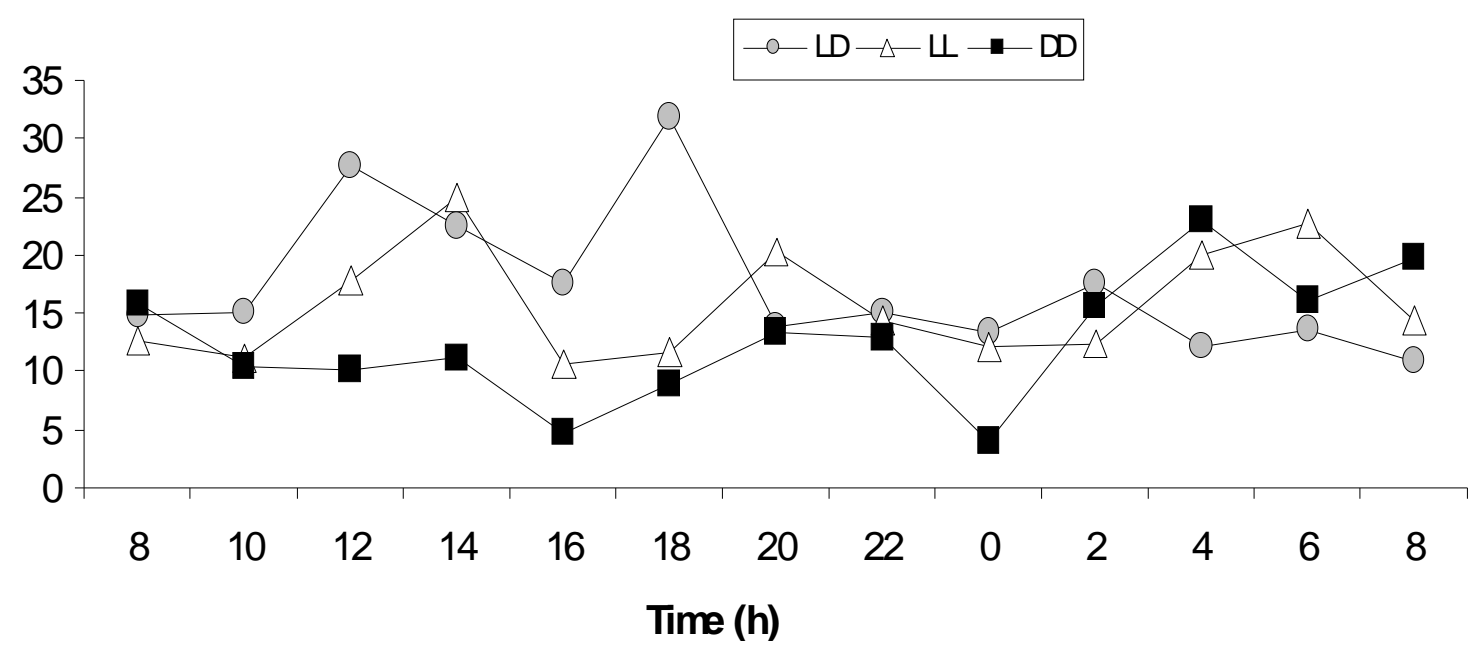

(B). Fat body amino acid rhythm- $\mathrm{V}$ instar (mg/g)

Fig. 3. Phase response curves (PRC) of the 24 -hr circadian amino acid rhythms in the fat body of (A) fourth instar (from $8 A M$ on day-3 to 8 AM on day-4) and (B) fifth instar (from 8AM on day-5 to 8 AM on day-6) larvae of Bombyx mori, under 12h light: $12 \mathrm{~h}$ dark cycle (LD); continuous light (LL) and continuous dark (DD) conditions (Source: Table 4.13). (P values: < 0.001).

$\mathrm{mg}$ ). Under DD, the range in amino acid rhythm varied in between $\sim 13$ to $46 \mathrm{mg}$, with peaks at $10 \mathrm{~h}(\sim 22 \mathrm{mg}), 18 \mathrm{~h}$ $(\sim 26 \mathrm{mg}), 00 \mathrm{~h}(46 \mathrm{mg})$ on day- 1 and $04 \mathrm{~h}(\sim 35 \mathrm{mg})$ and 06 $\mathrm{h}(\sim 28 \mathrm{mg})$ on day-2. Similarly, troughs in their levels were observed at $08 \mathrm{~h}(\sim 13 \mathrm{mg}), 12 \mathrm{~h}(\sim 19 \mathrm{mg}), 20 \mathrm{~h}(\sim 24$ $\mathrm{mg})$ and again next day at $02 \mathrm{~h}(\sim 34 \mathrm{mg})$ and $06 \mathrm{~h}(\sim 22$ $\mathrm{mg}$ ).

Fifth instar larval rhythms

Total proteins: Under 12:12 light / dark cycle (LD), the total protein rhythm of the fat body showed 7 peaks and 7 troughs (Fig. 2 A; Tables 3 and 4). Peaks appeared at 09 $\mathrm{h}$ (73 mg / g wet wt. of tissue) $13 \mathrm{~h}(\sim 84 \mathrm{mg}), 16 \mathrm{~h}(\sim 88$ $\mathrm{mg}), 21 \mathrm{~h}(\sim 79 \mathrm{mg}), 23 \mathrm{~h}(\sim 71 \mathrm{mg})$ and next day at $02 \mathrm{~h}(\sim 62$ $\mathrm{mg})$ and $07 \mathrm{~h}(\sim 61 \mathrm{mg})$. Similarly, troughs occurred at $10 \mathrm{~h}$ $(\sim 62 \mathrm{mg}), 15 \mathrm{~h}(\sim 47 \mathrm{mg}), 19 \mathrm{~h}(\sim 53 \mathrm{mg}), 22 \mathrm{~h}(66 \mathrm{mg}), 00 \mathrm{~h}$ $(36 \mathrm{mg})$ and next day at $04 \mathrm{~h}(\sim 46 \mathrm{mg})$ and $8 \mathrm{~h}(\sim 52 \mathrm{mg})$. Under LL, the total protein rhythm showed 8 peaks and 7 troughs. Peaks were recorded at $09 \mathrm{~h}(\sim 44 \mathrm{mg}), 13 \mathrm{~h}(42$ $\mathrm{mg}), 15 \mathrm{~h}(\sim 50 \mathrm{mg}), 20 \mathrm{~h}(\sim 49 \mathrm{mg}), 00 \mathrm{~h}(\sim 48 \mathrm{mg})$ and next day at $02 \mathrm{~h}(\sim 52 \mathrm{mg}), 04 \mathrm{~h}(\sim 55 \mathrm{mg})$ and $08 \mathrm{~h}(63 \mathrm{mg})$. Troughs occurred at $11 \mathrm{~h}(34 \mathrm{mg}), 14 \mathrm{~h}(\sim 34 \mathrm{mg}), 17 \mathrm{~h}$ $(\sim 34 \mathrm{mg}), 23 \mathrm{~h}(\sim 32 \mathrm{mg})$ and next day at $01 \mathrm{~h}(\sim 41 \mathrm{mg}), 03$ $\mathrm{h}(\sim 44 \mathrm{mg})$ and 06-07 h ( 41 mg each). Similarly, the phase response curve of the total protein rhythm recorded 7 peaks and 7 troughs under DD. Peaks occurred at $10 \mathrm{~h}$ ( 43 mg), $13 \mathrm{~h}(\sim 42 \mathrm{mg}), 18 \mathrm{~h}(\sim 54 \mathrm{mg}), 20 \mathrm{~h}(\sim 51 \mathrm{mg}), 22$ $\mathrm{h}(\sim 55 \mathrm{mg}), 00 \mathrm{~h}(\sim 52 \mathrm{mg})$ and next day again at $04 \mathrm{~h}(\sim 70$ $\mathrm{mg})$. Similarly, troughs appeared at $11 \mathrm{~h}(\sim 39 \mathrm{mg}), 14 \mathrm{~h}$ ( $34 \mathrm{mg}), 19 \mathrm{~h}(\sim 47 \mathrm{mg}), 21 \mathrm{~h}(\sim 48 \mathrm{mg}), 23 \mathrm{~h}(\sim 43 \mathrm{mg})$ and next day at $03 \mathrm{~h}(\sim 36 \mathrm{mg})$ and $08 \mathrm{~h}(\sim 40 \mathrm{mg})$. Though, the individual intervals between any two peaks or troughs ranged from 2 to $6 \mathrm{~h}$, the mean interval between any two peaks or troughs stood at $3.1 \mathrm{~h}$ under $\mathrm{LD}, \sim 2.8 \mathrm{~h}$ under both LL and DD (Fig. 2 A; Tables 3 and 4).

Soluble proteins: The free running time of the $24-\mathrm{h}$ soluble protein rhythm showed 7 peaks and 7 troughs under LD (Fig. 2 B; Tables 3 and 4). The peaks appeared at $10 \mathrm{~h}(\sim 56 \mathrm{mg}), 13 \mathrm{~h}(\sim 58 \mathrm{mg}), 16 \mathrm{~h}(\sim 72 \mathrm{mg}), 20 \mathrm{~h}(\sim 52$ 


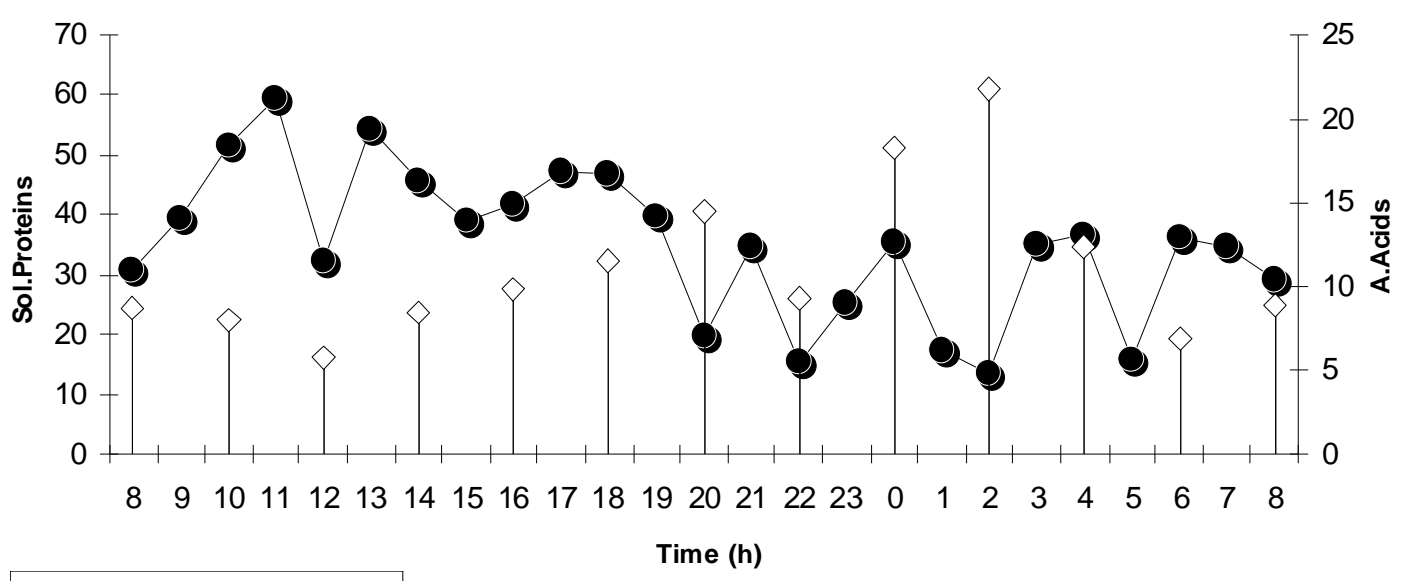

$\rightarrow$ Sol.Proteins $\leadsto$ A.Acids

(A). Fat body soluble proteins v/s amino acids (mg/g) in IV instar under LD.

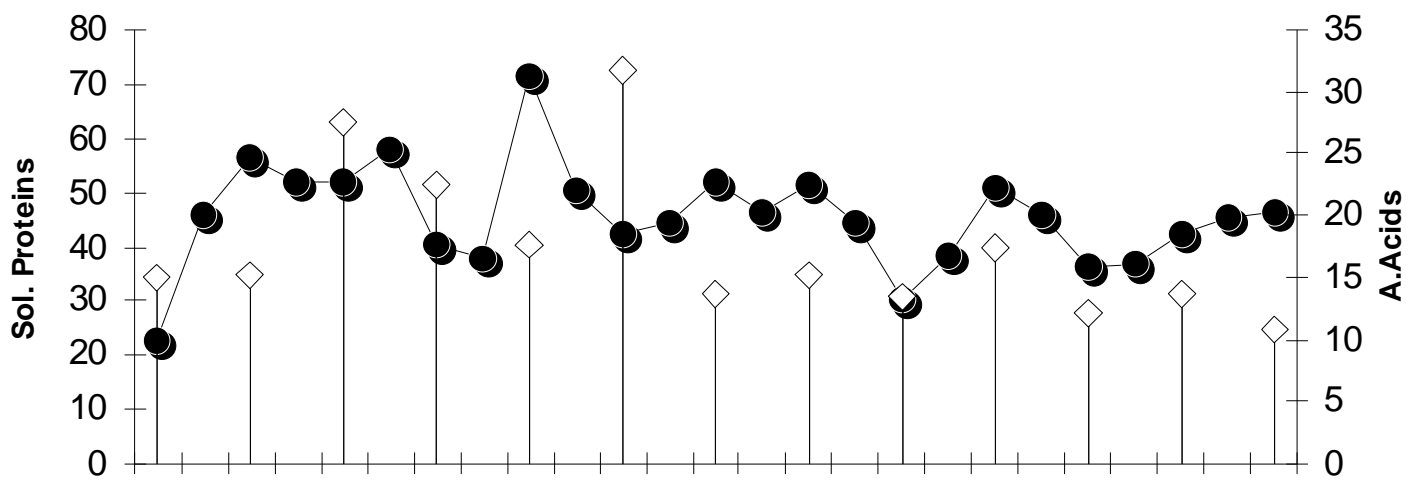

$8 \quad 91011121314151617181920212223241123 \quad 3 \quad 4 \quad 5 \quad 6 \quad 7 \quad 8$

Time (h)

(B). Fat body soluble proteins v/s amino acids (mg/g) in V instar under LD.

Fig.4. Circadian changes in profiles of soluble proteins and free amino acids in the fat body of Bombyx mori during fourth (A) and fifth (B) instar larval stages, under $12 \mathrm{~h}$ light: $12 \mathrm{hr}$ dark cycle (LD). The values expressed in mg per gm-wet weight of tissue, represent $24-h$ free running time of respective circadian rhythms. (P values: $<0.001)$.

$\mathrm{mg}), 22 \mathrm{~h}(\sim 52 \mathrm{mg})$ and next day at $02 \mathrm{~h}(\sim 51 \mathrm{mg})$ and $08 \mathrm{~h}$ $(\sim 46 \mathrm{mg})$. The troughs occurred at $08 \mathrm{~h}(\sim 23 \mathrm{mg}), 11-12 \mathrm{~h}$ ( $52 \mathrm{mg}$ each), $15 \mathrm{~h}(\sim 38 \mathrm{mg}), 18 \mathrm{~h}(\sim 42 \mathrm{mg}), 21 \mathrm{~h}(\sim 46$ $\mathrm{mg}), 00 \mathrm{~h}(\sim 30 \mathrm{mg})$ and next day at $04 \mathrm{~h}(\sim 36 \mathrm{mg})$. Under LL, the soluble protein rhythm showed 7 peaks and 7 troughs. The peaks appeared at $08 \mathrm{~h}(\sim 33 \mathrm{mg}), 13 \mathrm{~h}(\sim 29$ $\mathrm{mg}), 15 \mathrm{~h}(\sim 33 \mathrm{mg}), 18 \mathrm{~h}(\sim 28 \mathrm{mg}), 21 \mathrm{~h}(\sim 32 \mathrm{mg}), 02 \mathrm{~h}(\sim 44$ $\mathrm{mg})$ and next day at $02 \mathrm{~h}(\sim 44 \mathrm{mg})$ and $07 \mathrm{~h}(\sim 35 \mathrm{mg})$. The troughs appeared at $11-12 \mathrm{~h}(\sim 23 \mathrm{mg}), 14 \mathrm{~h}(\sim 30 \mathrm{mg}), 16 \mathrm{~h}$ $(\sim 22 \mathrm{mg}), 20 \mathrm{~h}(\sim 23 \mathrm{mg}), 23 \mathrm{~h}(\sim 28 \mathrm{mg})$, and next day at 03 $\mathrm{h}(\sim 30 \mathrm{mg})$ and $08 \mathrm{~h}(\sim 32 \mathrm{mg})$. Under DD, the phase response curve of the soluble protein rhythm showed 7 peaks and 7 troughs. The peaks occurred at $10 \mathrm{~h}(32 \mathrm{mg})$, $12 \mathrm{~h}(\sim 34 \mathrm{mg}), 18 \mathrm{~h}(\sim 40 \mathrm{mg}), 20 \mathrm{~h}(\sim 37 \mathrm{mg}), 22 \mathrm{~h}(\sim 35 \mathrm{mg})$, $00 \mathrm{~h}(\sim 37 \mathrm{mg})$ and next day at $04 \mathrm{~h}(\sim 51 \mathrm{mg})$. The troughs appeared at $11 \mathrm{~h}(\sim 31 \mathrm{mg}), 14 \mathrm{~h}(\sim 21 \mathrm{mg}), 19 \mathrm{~h}(\sim 35 \mathrm{mg})$, $21 \mathrm{~h}(\sim 18 \mathrm{mg}), 23 \mathrm{~h}(\sim 33 \mathrm{mg})$ and next day at $01-02-03 \mathrm{~h}$ ( $\sim 30 \mathrm{mg}$ each) and $07-08 \mathrm{~h}(\sim 18 \mathrm{mg}$ each). Though, the individual intervals between any two peaks or troughs ranged from 2 to $6 \mathrm{~h}$, the mean interval between any two peaks or troughs stood at $2.9 \mathrm{~h}$ under LD, $3.1 \mathrm{~h}$ under $\mathrm{LL}$ and 2.6 h under DD (Fig. 2 B; Tables 3 and 4).
Structural proteins: Under LD, the phase response curve of structural protein rhythm showed 7 peaks and 7 troughs (Fig. $2 \mathrm{C}$; Tables 3 and 4). The peaks appeared at $8 \mathrm{~h}(\sim 48 \mathrm{mg}), 13 \mathrm{~h}(\sim 26 \mathrm{mg}), 16 \mathrm{~h}(\sim 17 \mathrm{mg}), 21 \mathrm{~h}(\sim 32 \mathrm{mg})$, $23 \mathrm{~h}(\sim 27 \mathrm{mg})$ and next day at $01 \mathrm{~h}(\sim 23 \mathrm{mg})$ and $07 \mathrm{~h}(\sim 16$ $\mathrm{mg})$. With regard to troughs, they occurred at $10 \mathrm{~h}(\sim 6$ $\mathrm{mg}), 15 \mathrm{~h}(\sim 9 \mathrm{mg}), 19 \mathrm{~h}(\sim 8 \mathrm{mg}), 22 \mathrm{~h}(\sim 15 \mathrm{mg}), 00 \mathrm{~h}(\sim 6$ $\mathrm{mg})$ and next day at $04 \mathrm{~h}(10 \mathrm{mg})$ and $08 \mathrm{~h}(\sim 6 \mathrm{mg})$. Under LL, 8 peaks and 8 troughs were observed in the structural protein rhythm. Peaks appeared at $10 \mathrm{~h}(\sim 13 \mathrm{mg}), 13 \mathrm{~h}$ $(\sim 13 \mathrm{mg}), 16 \mathrm{~h}(\sim 20 \mathrm{mg}), 20 \mathrm{~h}(\sim 26 \mathrm{mg}), 22 \mathrm{~h}(\sim 9 \mathrm{mg}), 00 \mathrm{~h}$ $(\sim 18 \mathrm{mg})$ and next day at $04 \mathrm{~h}(\sim 25 \mathrm{mg})$ and $08 \mathrm{~h}(\sim 31 \mathrm{mg})$. As regards troughs, they appeared at $08 \mathrm{~h}(\sim 10 \mathrm{mg}), 11 \mathrm{~h}$ $(\sim 11 \mathrm{mg}), 14 \mathrm{~h}(\sim 5 \mathrm{mg}), 18 \mathrm{~h}(\sim 8 \mathrm{mg}), 21 \mathrm{~h}(\sim 7 \mathrm{mg}), 23 \mathrm{~h}(\sim 4$ $\mathrm{mg})$ and next day at $01 \mathrm{~h}(\sim 7 \mathrm{mg})$ and $07 \mathrm{~h}(\sim 6 \mathrm{mg})$. Under $\mathrm{DD}$, the structural protein rhythm displayed 7 peaks and 7 troughs. As regards peaks, they appeared at $10 \mathrm{~h}(\sim 11$ $\mathrm{mg}), 15 \mathrm{~h}(\sim 15 \mathrm{mg}), 18 \mathrm{~h}(\sim 15 \mathrm{mg}), 20 \mathrm{~h}(\sim 14 \mathrm{mg}), 00 \mathrm{~h}(15$ $\mathrm{mg})$ and next day at $04 \mathrm{~h}(\sim 19 \mathrm{mg})$ and $07 \mathrm{~h}(\sim 23 \mathrm{mg})$. The troughs occurred at $09 \mathrm{~h}(9 \mathrm{mg}), 12 \mathrm{~h}(\sim 7 \mathrm{mg}), 16 \mathrm{~h}(\sim 13$ $\mathrm{mg}), 19 \mathrm{~h}(\sim 12 \mathrm{mg}), 23 \mathrm{~h}(\sim 10 \mathrm{mg})$ and next day at $03 \mathrm{~h}(\sim 6$ $\mathrm{mg})$ and $06 \mathrm{~h}(\sim 13 \mathrm{mg})$. Though, the individual intervals 

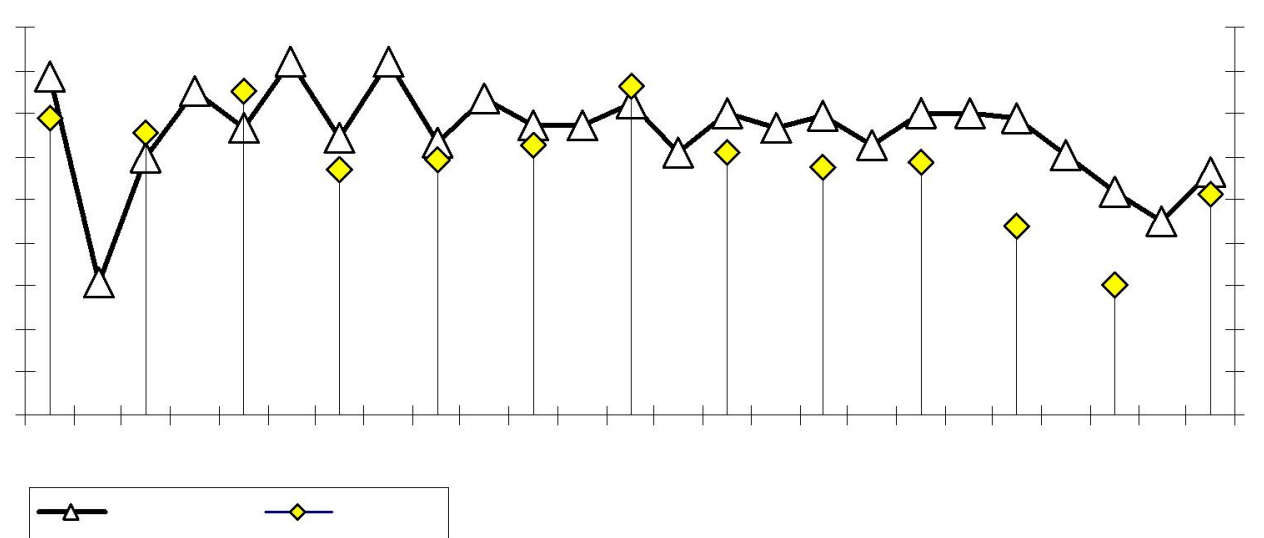

(A). Fat body soluble proteins v/s amino acids $(\mathrm{mg} / \mathrm{g})$ in IV instar under LL.
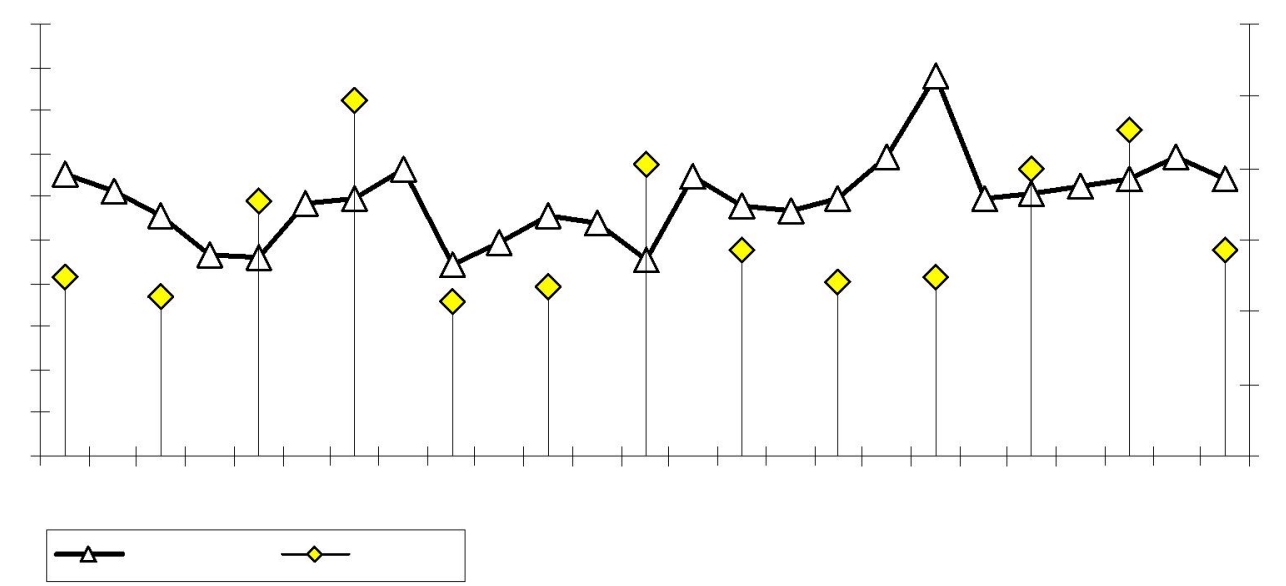

(B). Fat body soluble proteins v/s amino acids ( $\mathrm{mg} / \mathrm{g}$ ) in $\mathrm{V}$ instar under LL.

Fig. 5. Circadian changes in profiles of soluble proteins and free amino acids in the fat body of Bombyx mori during fourth (A) and fifth (B) instar larval stages, under continuous light (LL). The values expressed in mg per gm-wet weight of tissue, represent 24-h free running time of respective circadian rhythms. (P values: $<0.001$ ).

between any two peaks or troughs ranged from 2 to $6 \mathrm{~h}$, the mean interval between any two peaks or troughs stood at $3.2 \mathrm{~h}$ under LD, $\sim 2.9 \mathrm{~h}$ under LL and $\sim 3 \mathrm{~h}$ under DD (Fig. 2 C; Tables 3 and 4).

Free amino acids: The fifth instar circadian amino acid rhythm differs slightly from that of the fourth instar (Fig. $3 \mathrm{~B})$, in which higher levels of free amino acids ( 11 mg to $\sim 32 \mathrm{mg}$ ) were recorded under LD compared to LL $(\sim 11$ $\mathrm{mg}$ to $25 \mathrm{mg}$ ) and DD ( 4 mg $23 \mathrm{mg})$. Under LD, peaks in free amino acid levels were observed at $12 \mathrm{~h}(\sim 28 \mathrm{mg}), 18$ $\mathrm{h}$ ( $\sim 32 \mathrm{mg}), 22 \mathrm{~h}(\sim 15 \mathrm{mg}), 02 \mathrm{~h}(\sim 17 \mathrm{mg})$ and again next day at $06 \mathrm{~h}(\sim 14 \mathrm{mg})$ and troughs were observed at $08-10$ h ( 15 mg each) 16h ( 18 mg), $20 \mathrm{~h}(\sim 14 \mathrm{mg}), 00 \mathrm{~h}(13 \mathrm{mg})$, and next day at $04 \mathrm{~h}(\sim 12 \mathrm{mg})$ and $06 \mathrm{~h}(11 \mathrm{mg})$. Under LL, free amino acid levels recorded peaks at $14 \mathrm{~h}(\sim 25 \mathrm{mg})$, $20 \mathrm{~h}(\sim 20 \mathrm{mg})$ and again next day at $06 \mathrm{~h}(23 \mathrm{mg})$ and troughs at $08 \mathrm{~h}(\sim 13 \mathrm{mg}), 16 \mathrm{~h}(\sim 11 \mathrm{mg})$ and $00 \mathrm{~h}(\sim 12 \mathrm{mg})$ and next day at $08 \mathrm{~h}$ ( $14 \mathrm{mg})$. Similarly, under DD, peaks in their levels were observed at $08 \mathrm{~h}(\sim 16 \mathrm{mg}), 14 \mathrm{~h}(\sim 11$ $\mathrm{mg})$ and 20-22 $\mathrm{h}(\sim 13 \mathrm{mg}$ each) and again next day at 04 $\mathrm{h}(\sim 23 \mathrm{mg})$ and $06 \mathrm{~h}(\sim 20 \mathrm{mg})$ while troughs were observed at $10 \mathrm{~h}(\sim 10 \mathrm{mg}) 16 \mathrm{~h}(\sim 5 \mathrm{mg}), 00 \mathrm{~h}(\sim 4 \mathrm{mg})$ and next day at $06 \mathrm{~h}(\sim 16 \mathrm{mg})$.
In both fourth and fifth instars, the free running period of the protein and free amino acid rhythms maintained constant fluctuations that are not statistically significant to be counted as peaks and troughs under all the three photoperiodic conditions; LD, LL and DD (Figs. 1, 2 and 3).

\section{DISCUSSION}

The silkworm fat body being a major site of metabolism, synthesizes and stores over 177 proteins that includes nine glycolysis related proteins, several metabolically related proteins like diacylglycerol binding protein, triacylglycerol lipase, putative hydrolases, cytoskeleton proteins, defence proteins, heat shock proteins, $30 \mathrm{~K}$ proteins and actin (Hou et al., 2007). The current study demonstrates that the fat body proteins in B. mori show time-bound circadian changes that are probably triggered by tissue-specific endogenous pace makers, much like that in other insects (Shimizu et al., 2001; Sehadova et al., 2004; Iwai et al., 2006; Kyung et al., 2006). Though, the rhythm of particular protein is not examined in the present study, it might relate to a multitude of proteins that are synthesized from time to time during larval development. 

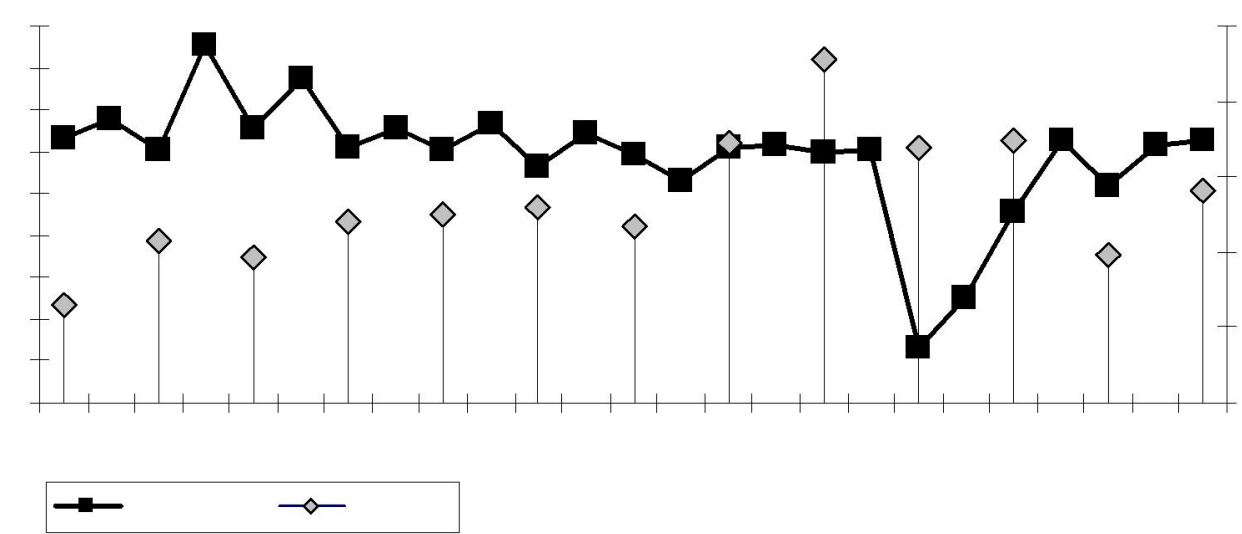

(A). Fat body soluble proteins v/s amino acids ( $\mathrm{mg} / \mathrm{g})$ in IV instar under.
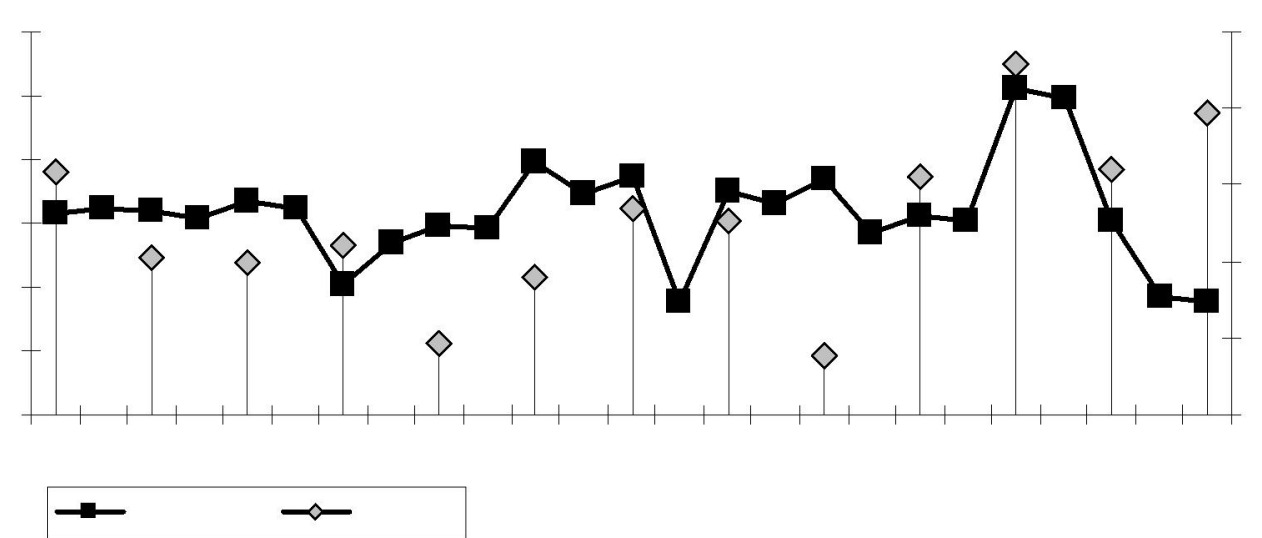

(B). Fat body soluble proteins v/s amino acids (mg/g) in V instar under DD.

Fig. 6. Circadian changes in profiles of soluble proteins and free amino acids in the fatbody of Bombyx mori during fourth (A) and fifth (B) instar larval stages, under continuous dark (DD). The values expressed in mg per gm-wet weight of tissue, represent 24$\mathrm{h}$ free running time of respective circadian rhythms. (P values: $<0.001$ ).

As reported in our previous reports for the silk gland (Sailaja and Sivaprasad, $2010 \mathrm{a}, \mathrm{b}$ ), the peaks and troughs of the phase response curves (PRCs) of the fat body protein rhythm probably indicate two vital stages of gene expression; translation (protein synthesis) and transcription, and the combined mean interval between a peak and trough reflects the duration of each protein synthetic cycle. Though, the ups and downs in protein profiles were earlier linked with mechanisms such as the shuttling of clock related proteins between nucleoplasm and cytoplasm, intracellular proteolysis (Chen and You, 2004; Ciechanover, 2005) and protein consolidation processes such as gelation, adhesion and crystallization (Inoue et al., 2000; Takasu et al., 2005). Though photoperiod-specific clock-shifting is reflected in the protein rhythm, it is not so with reference to larval stage, as both the fourth and fifth instar larval stages depicted 7 PS cycles under LD condition. Nevertheless, the longer duration of fifth instar (7 or 8 days) ensures the synthesis of additional proteins in about 49 or 56 PS cycles ( $7 \times 7$ $=49$ or $7 \times 8=56$ ) compared to short duration of the fourth instar (4 days) that shows only 28 PS cycles ( $7 \times 4$ $=28$ ). Thus, large number of PS cycles during the fifth instar development contributes to heavy toll of proteins (Figs. 1 and 2) that are associated with metabolic events of larval-pupal transformation. This obviously is sustained by the recruitment of more and more genes in the fat body similar to that in the silk gland (Sailaja and Sivaprasad, $2010 \mathrm{a}, \mathrm{b}$ ). It is not known as to which genes are expressed and which proteins are synthesized during the protein rhythm. More studies on silkworm proteomics and genomics are needed to elucidate this fact.

Photoperiod-specific clock-shifting: Our findings suggest that the photoperiod has clock-shifting effect on the free running time of the fat body protein rhythm that significantly alters the number of PS cycles either by extending or by retarding the duration of each cycle in both the instars examined (Table 5). In the fourth instar, the number of PS cycles, which was 7 under LD, increased to 9.5 under LL and 8 under DD. At the same time the duration of each cycle, which was about $3.4 \mathrm{~h}$ under LD, is reduced to $2.5 \mathrm{~h}$ under $\mathrm{LL}$ (a reduction of $0.9 \mathrm{~h}$ or $54 \mathrm{~m}$ ) and to $3.0 \mathrm{~h}$ under DD (a reduction of $0.4 \mathrm{~h}$ or $24 \mathrm{~m}$ ). The shift in the protein rhythm during fifth instar is more or less similar to that of fourth instar. The number of PS cycles, which was 7 under LD, increased to 7.5 under LL, 
Table 1. Interval between peaks (elevated points) of protein levels in the fatbody of the fourth instar larva of B ombyx mori during the free running period of the rhythm under $12 \mathrm{hrs}$ light/ dark cycle (LD), continuous light (LL) and continuous dark (DD) conditions.

\begin{tabular}{|c|c|c|c|c|c|c|c|c|c|c|c|c|}
\hline \multirow[t]{2}{*}{ Protein type } & \multirow{2}{*}{$\begin{array}{l}\text { Photo- } \\
\text { period }\end{array}$} & \multirow{2}{*}{$\begin{array}{l}\text { No. of } \\
\text { peaks }\end{array}$} & \multicolumn{9}{|c|}{ Interval between peaks in hours } & \multirow{2}{*}{$\begin{array}{c}\text { M ean } \\
\text { inter val in } \\
\text { hours }\end{array}$} \\
\hline & & & $1-2$ & $2-3$ & $3-4$ & $4-5$ & $5-6$ & $6-7$ & $7-8$ & $8-9$ & $9-10$ & \\
\hline \multirow{3}{*}{$\begin{array}{l}\text { Total } \\
\text { Proteins }\end{array}$} & $\mathrm{LD}$ & 6 & 2 & 4 & 5 & 6 & 3 & - & - & - & - & 3.3 \\
\hline & LL & 10 & 3 & 2 & 2 & 2 & 5 & 2 & 2 & 2 & 4 & 2.4 \\
\hline & DD & 8 & 3 & 4 & 5 & 3 & 2 & 4 & 2 & - & - & 2.9 \\
\hline \multirow{3}{*}{$\begin{array}{l}\text { Soluble } \\
\text { proteins }\end{array}$} & LD & 7 & 2 & 5 & 3 & 3 & 4 & 2 & - & - & - & 2.7 \\
\hline & LL & 10 & 3 & 2 & 2 & 2 & 3 & 2 & 2 & 2 & 4 & 2.2 \\
\hline & DD & 9 & 4 & 2 & 2 & 2 & 2 & 3 & 6 & 3 & - & 2.7 \\
\hline \multirow{3}{*}{$\begin{array}{l}\text { Structural } \\
\text { Proteins }\end{array}$} & LD & 8 & 4 & 5 & 3 & 2 & 3 & 4 & 2 & - & - & 2.9 \\
\hline & LL & 9 & 4 & 2 & 3 & 5 & 3 & 2 & 2 & 3 & - & 2.7 \\
\hline & DD & 8 & 4 & 3 & 5 & 3 & 2 & 3 & 3 & - & - & 2.9 \\
\hline
\end{tabular}

Source: Figs. 1, 2,3

but remained unchanged under DD. The duration of each cycle is maintained at $3.4 \mathrm{~h}$ under both LD and DD, but declined by $0.2 \mathrm{~h}$ or $12 \mathrm{~m}$ (from $3.4 \mathrm{~h}$ to $3.2 \mathrm{~h}$ ) under LL (Table 5). Accordingly, when the growing silkworm larvae are exposed to different photoperiodic cues, the circadian protein rhythm shifts from the standard $24 \mathrm{hr}$-pattern. In the fourth instar larvae, the shift results in decreasing the free running time from normal $24 \mathrm{~h}$ to $17.5 \mathrm{~h}$ under LL and $21 \mathrm{~h}$ under DD, thus advancing the rhythm by $6 \mathrm{~h}$ and $30 \mathrm{~m}(24-17.5=6.5 \mathrm{hr})$ under LL and by $3 \mathrm{~h}(24-21$ $=3 \mathrm{~h}$ ) under DD. But in the fifth instar larva, the $24 \mathrm{~h}$-free running time is clock-shifted to $22.4 \mathrm{~h}(22 \mathrm{~h}, 24 \mathrm{~m})$ under LL, but remained the same under DD (Table 5). The increase in the number of PS cycles under LL and DD conditions observed in B. mori is in close agreement with the earlier observations in crickets and other insects that more proteins are synthesized under altered conditions of photoperiod (Kenny and Saunders, 1991; Koga et al.,
2005; Peschel et al., 2009).

As projected for the silk gland (Sailaja and Sivaprasad, $2010 \mathrm{a}, \mathrm{b})$, the photoperiod-induced changes in the fat body protein rhythm reflect corresponding changes in the timing of gene expression. Obviously, the genes in the fat body cells express 7 times under LD, 9.5 times under LL and 8 times under DD at intervals of $3.4 \mathrm{~h}, 2.5 \mathrm{~h}$ and $3 \mathrm{~h}$ respectively under the three photoperiodic conditions. Similarly, in the fifth instar, they express 7 times under LD and DD (at 3. 4 h intervals) and 8 times under LL (at $3 \mathrm{~h}$ intervals). Thus, the fat body maintains a constant or altered rhythm even in darkness (DD), probably by taking cues from the diet that acts as an alternative zeitgeber (time giver) to light and quickly resets the clock in peripheral organs (Damiola et al., 2000; Stokkan et al., 2001; Kita et al., 2002) such as the fat body. Since, the silkworms, reared under DD were also fed 5 times a day, they carried through the rhythm much

Table 2. Interval between troughs (low points) of protein levels in the fatbody of the fourth instar larva of Bombyx mori during the free running period of the rhythm under 12hrs light / dark cycle (LD), continuous light (LL) and continuous dark (DD) conditions.

\begin{tabular}{|c|c|c|c|c|c|c|c|c|c|c|c|c|}
\hline \multirow[t]{2}{*}{ Protein type } & \multirow{2}{*}{$\begin{array}{l}\text { Photo- } \\
\text { period }\end{array}$} & \multirow{2}{*}{$\begin{array}{l}\text { No. of } \\
\text { troughs }\end{array}$} & \multicolumn{9}{|c|}{ Interval between tr oughs in hours } & \multirow{2}{*}{$\begin{array}{c}\text { M ean } \\
\text { interval in } \\
\text { hours }\end{array}$} \\
\hline & & & $1-2$ & $2-3$ & $3-4$ & $4-5$ & $5-6$ & $6-7$ & $7-8$ & $8-9$ & $9-10$ & \\
\hline \multirow{3}{*}{$\begin{array}{l}\text { Total } \\
\text { Proteins }\end{array}$} & LD & 6 & 4 & 3 & 5 & 6 & 4 & - & - & - & - & 3.7 \\
\hline & LL & 9 & 3 & 2 & 2 & 2 & 5 & 2 & 2 & 3 & - & 2.3 \\
\hline & DD & 8 & 5 & 2 & 2 & 4 & 4 & 4 & 2 & - & - & 2.9 \\
\hline \multirow{3}{*}{$\begin{array}{l}\text { Soluble } \\
\text { proteins }\end{array}$} & $\mathrm{LD}$ & 8 & 4 & 3 & 5 & 2 & 4 & 3 & 3 & - & - & 3.0 \\
\hline & LL & 9 & 3 & 2 & 2 & 2 & 2 & 2 & 2 & 6 & - & 2.3 \\
\hline & DD & 9 & 2 & 2 & 2 & 2 & 2 & 3 & 5 & 4 & - & 2.4 \\
\hline \multirow{3}{*}{$\begin{array}{l}\text { Structural } \\
\text { Proteins }\end{array}$} & $\mathrm{LD}$ & 8 & 5 & 3 & 3 & 3 & 3 & 3 & 2 & - & - & 2.8 \\
\hline & LL & 9 & 2 & 2 & 3 & 3 & 5 & 2 & 2 & 3 & - & 2.4 \\
\hline & DD & 8 & 4 & 4 & 5 & 2 & 2 & 3 & 3 & - & - & 2.9 \\
\hline
\end{tabular}

Source: Figs. 1, 2,3 
Table 3. Interval between peaks (elevated points) of protein levels in the fat body of the fifth instar larva of B ombyx mori during the free running period of the rhythm under $12 \mathrm{hrs} \mathrm{light/} \mathrm{dark} \mathrm{cycle} \mathrm{(LD),} \mathrm{continuous} \mathrm{light} \mathrm{(LL)} \mathrm{and} \mathrm{continuous} \mathrm{dark} \mathrm{(DD)}$ conditions.

\begin{tabular}{|c|c|c|c|c|c|c|c|c|c|c|c|c|}
\hline \multirow[t]{2}{*}{ Protein type } & \multirow{2}{*}{$\begin{array}{l}\text { Photo- } \\
\text { period }\end{array}$} & \multirow{2}{*}{$\begin{array}{l}\text { No. of } \\
\text { peaks }\end{array}$} & \multicolumn{9}{|c|}{ Interval between peaks in hours } & \multirow{2}{*}{$\begin{array}{c}\text { M ean } \\
\text { interval in } \\
\text { hours }\end{array}$} \\
\hline & & & $1-2$ & $2-3$ & $3-4$ & $4-5$ & $5-6$ & $6-7$ & $7-8$ & $8-9$ & $9-10$ & \\
\hline & LD & 7 & 4 & 3 & 5 & 2 & 3 & 5 & - & - & - & 3.1 \\
\hline Total & LL & 8 & 4 & 2 & 5 & 4 & 2 & 2 & 4 & - & - & 2.9 \\
\hline \multirow[t]{2}{*}{ Proteins } & DD & 7 & 3 & 5 & 2 & 2 & 2 & 4 & - & - & - & 2.6 \\
\hline & LD & 7 & 3 & 3 & 4 & 2 & 4 & 6 & - & - & - & 3.1 \\
\hline Soluble & LL & 7 & 5 & 2 & 3 & 3 & 5 & 5 & - & - & - & 3.3 \\
\hline proteins & $\mathrm{DD}$ & 7 & 2 & 6 & 2 & 2 & 2 & 4 & - & - & - & 2.6 \\
\hline Structural & LD & 7 & 5 & 3 & 5 & 2 & 2 & 6 & - & - & - & 3.3 \\
\hline \multirow[t]{2}{*}{ Proteins } & LL & 8 & 3 & 3 & 4 & 2 & 2 & 4 & 4 & - & - & 2.8 \\
\hline & DD & 7 & 5 & 3 & 3 & 3 & 4 & 3 & - & - & - & 3.0 \\
\hline
\end{tabular}

Source: Figs. 4, 5, 6

like those reared under LD and LL, a fact that indicates the existence of at least two-oscillators in the fat body of B. mori, that respond separately for light and dark cues as observed in D rosophila (Forster, 2000). The studies on insect clock genes and their expression timings (Syrova et al., 2003; Grima et al., 2004;Hardin, 2004; Shafer et al., 2004; Stoleru et al., 2004) and on some physiological parameters (Koga et al., 2005; Kanyan Xu, 2008) lend credibility to the existence of peripheral oscillators in B. mori. Hopefully, our findings (Sailaja and Sivaprasad, $2010 \mathrm{a}, \mathrm{b}$ ) on the silk gland protein rhythms could provide further conclusive proof for the clock-shifting nature of the light in stage-specific and tissue-specific manners in the fat body of silkworm. While, the scoto (dark) phase causes elevation in peak heights, the photo (light) phase increases the number of peaks during the free running time of the protein rhythm (Fig. 2 A, B, C). Evidently, the intensity (height of peaks) and frequency (number of peaks) of silk gene expression in B. mori are independently modulated by the dark and light cues respectively, for which conclusive proof is not available. Nevertheless, the photoperiod undoubtedly causes behavioural adjustments by resetting the timing of the expression of the circadian clock genes in the fat body.

Protein rhythm ver sus free amino acids: Since amino acids are the building blocks of proteins, the protein rhythm rises and falls with the levels of free amino acids (FAA). Since, the soluble proteins represent most of the freshly synthesized proteins; a comparative account of their PRCs vis-a-vis the FAA rhythm help in drawing meaningful conclusions with regard to the instar-specific and photoperiod-specific relationship between these two biochemical constituents. As shown in figures 4, 5 and 6, the protein synthetic phases (peaks) are preceded by elevations in the levels of free amino acids notwithstanding some minor deviations occurred

Table 4. Interval between troughs (low points) of protein levels in the fat body of the fifth instar larva of Bombyx mori during the free running period of the rhythm under $12 \mathrm{hrs} \mathrm{light} \mathrm{/} \mathrm{dark} \mathrm{cycle} \mathrm{(LD),} \mathrm{continuous} \mathrm{light} \mathrm{(LL)} \mathrm{and} \mathrm{continuous} \mathrm{dark} \mathrm{(DD)}$ conditions

\begin{tabular}{|c|c|c|c|c|c|c|c|c|c|c|c|c|}
\hline \multirow[t]{2}{*}{ Protein type } & \multirow{2}{*}{$\begin{array}{l}\text { Photo- } \\
\text { period }\end{array}$} & \multirow{2}{*}{$\begin{array}{l}\text { No. of } \\
\text { troughs }\end{array}$} & \multicolumn{9}{|c|}{ Interval between troughs in hours } & \multirow{2}{*}{$\begin{array}{c}\text { M ean } \\
\text { interval in } \\
\text { hours }\end{array}$} \\
\hline & & & $1-2$ & $2-3$ & $3-4$ & $4-5$ & $5-6$ & $6-7$ & $7-8$ & $8-9$ & $9-10$ & \\
\hline \multirow{3}{*}{$\begin{array}{l}\text { Total } \\
\text { Proteins }\end{array}$} & $\mathrm{LD}$ & 7 & 5 & 4 & 3 & 2 & 4 & 4 & - & - & - & 3.1 \\
\hline & LL & 7 & 3 & 3 & 6 & 2 & 2 & 3 & - & - & - & 2.7 \\
\hline & DD & 7 & 3 & 5 & 2 & 2 & 4 & 5 & - & - & - & 3.0 \\
\hline \multirow{3}{*}{$\begin{array}{l}\text { Soluble } \\
\text { proteins }\end{array}$} & $\mathrm{LD}$ & 7 & 3 & 3 & 3 & 3 & 3 & 4 & - & - & - & 2.7 \\
\hline & LL & 7 & 2 & 2 & 4 & 3 & 4 & 5 & - & - & - & 2.9 \\
\hline & DD & 7 & 3 & 5 & 2 & 2 & 2 & 4 & - & - & - & 2.6 \\
\hline \multirow{3}{*}{$\begin{array}{l}\text { Structural } \\
\text { Proteins }\end{array}$} & LD & 7 & 5 & 4 & 3 & 2 & 4 & 4 & - & - & - & 3.1 \\
\hline & LL & 8 & 3 & 3 & 4 & 3 & & 2 & 6 & - & - & 2.9 \\
\hline & DD & 7 & 3 & 4 & 3 & 4 & 4 & 3 & - & - & - & 3.0 \\
\hline
\end{tabular}

Source: Figs.4, 5,6 
Table 5. Comparative analysis of the phase response curves of the protein rhythms in the fatbody of the fourth and fifth instar larvae of B ombyx mori, in terms of mean number of peaks and troughs and the mean interval between them, under $12 \mathrm{~h}$ light / dark cycle (LD), continuous light (LL) and continuous dark (DD) conditions.

\begin{tabular}{|c|c|c|c|c|c|c|}
\hline \multirow[b]{2}{*}{ Parameter } & \multicolumn{3}{|c|}{ Fourth instar } & \multicolumn{3}{|c|}{ Fifth instar } \\
\hline & LD & $\mathrm{LL}$ & DD & LD & LL & $\mathrm{DD}$ \\
\hline Average number of peaks & 7 & $\sim 10$ & $\sim 8$ & 7 & $\sim 8$ & 7 \\
\hline Average number of troughs & $\sim 7$ & 9 & $\sim 8$ & 7 & $\sim 7$ & 7 \\
\hline Mean interval between peaks & $\sim 3 \mathrm{~h}$ & $\sim 2 \mathrm{~h}$ & $\sim 2.8 \mathrm{~h}$ & $\sim 3.2 \mathrm{~h}$ & $3.0 \mathrm{~h}$ & $\sim 2.7 \mathrm{~h}$ \\
\hline Mean interval between troughs & $\sim 3.2 \mathrm{~h}$ & $\sim 2.3 \mathrm{~h}$ & $\sim 2.7 \mathrm{~h}$ & $\sim 3 \mathrm{~h}$ & $\sim 2.8 \mathrm{~h}$ & $\sim 2.9 \mathrm{~h}$ \\
\hline $\begin{array}{l}\text { Combined mean interval of } \\
\text { peaks and troughs }\end{array}$ & $\sim 3 \mathrm{~h}$ & $\sim 2.2 \mathrm{~h}$ & $\sim 2.8 \mathrm{~h}$ & $3.1 \mathrm{~h}$ & $2.9 \mathrm{~h}$ & $2.8 \mathrm{~h}$ \\
\hline $\begin{array}{l}\text { Probable number of protein } \\
\text { synthetic cycles }\end{array}$ & 7 & 9.5 & 8 & 7 & 7.5 & 7 \\
\hline $\begin{array}{l}\text { Time taken for each protein } \\
\text { synthetic cycle }\end{array}$ & $\begin{array}{c}3.4 \mathrm{~h} \\
(24 / 7=3.4)\end{array}$ & $\begin{array}{c}2.5 \mathrm{~h} \\
(24 / 9.5=2.5)\end{array}$ & $\begin{array}{c}3 \mathrm{~h} \\
(24 / 8=3)\end{array}$ & $\begin{array}{c}3.4 \mathrm{~h} \\
(24 / 7=3.4)\end{array}$ & $\begin{array}{c}3.2 \mathrm{~h} \\
(24 / 7.5=3.2)\end{array}$ & $\begin{array}{c}3.4 \mathrm{~h} \\
(24 / 7=3.4)\end{array}$ \\
\hline Free running time & $\begin{array}{c}24 \mathrm{~h} \\
(3.4 \times 7=23.8)\end{array}$ & $\begin{array}{c}17.5 \mathrm{~h} \\
(2.5 \times 7=17.5)\end{array}$ & $\begin{array}{c}21 \mathrm{~h} \\
(3 \times 7=21)\end{array}$ & $\begin{array}{c}24 \mathrm{~h} \\
(3.4 \times 7=23.8)\end{array}$ & $\begin{array}{c}22.4 \mathrm{~h} \\
(3.2 \times 7=22.4)\end{array}$ & $\begin{array}{c}24 \mathrm{~h} \\
(3.4 \times 7=23.8)\end{array}$ \\
\hline
\end{tabular}

Source: Figs. 1, 2, 3 for fourth instar and 5, 6, 7 for fifth instar.

probably due to sampling errors.

Under LD, the FAA pool available at a particular hour, is used up either in the same PS cycle or in the subsequent cycles in the next one or two hours. In the fourth instar, for instance, the rise in the levels of FAA at 8-10 h, 12h, 14-18h, $20 \mathrm{~h}, 22 \mathrm{~h}, 02 \mathrm{~h}$ and 6-8 h on second day are usedup in the PS cycles occurred at 8-12 h, 13 h, 16-18 h, $21 \mathrm{~h}$, 23-00 h, 3-4 h, and at 6-8 h respectively (Fig. 4 A). Similarly, in the fifth instar, the elevations in the FAA levels at $8 \mathrm{~h}$, $10 \mathrm{~h}, 12 \mathrm{~h}, 14-16 \mathrm{~h}, 18 \mathrm{~h}, 20-22 \mathrm{~h}, 00 \mathrm{~h}, 02 \mathrm{~h}$, and $4-8 \mathrm{~h}$ were accompanied by peaks in soluble protein levels at $9 \mathrm{~h}$, 10-11 h, 13 h, 16-17h, 19-20 h, 20-22 h, 1 h, 2-3 h and 4-8 h respectively (Fig. $4 \mathrm{~B}$ ). Thus, the ongoing PS cycles are sustained by free amino acid inputs from time to time during the free running time of the protein rhythm.

The situation under LL is slightly different. In both the fourth and fifth instars, the FAA levels at a particular hour are proceeded by an increase in the levels of soluble proteins, indicating their utilization within one hour after their availability. As shown in the figure $5 \mathrm{~A}$, the rise in the FAA levels at $8 \mathrm{~h}, 10 \mathrm{~h}, 12 \mathrm{~h}, 14 \mathrm{~h}, 16 \mathrm{~h}, 18 \mathrm{~h}, 20 \mathrm{hrs}, 22-$ $00 \mathrm{~h}, 02-04 \mathrm{~h}$ and at $06-08 \mathrm{hr}$ was proceeded by corresponding increase in the levels of proteins at $8 \mathrm{~h}$, 10-11 h, 13 h, 15 h, 17 h, 18-19 h, 20 h, 22-00 h, 02-04 h and next day at $08 \mathrm{~h}$ in the fourth instar lava. Similarly, in the fifth instar larval stage, the rise in FAA levels at $08 \mathrm{~h}, 10$ $12 \mathrm{~h}, 16-18 \mathrm{~h}, 20 \mathrm{~h}, 22-02 \mathrm{~h}$ and 04-06 h, were accompanied by elevation in the soluble protein levels at $08 \mathrm{~h}, 13-15 \mathrm{~h}$, 16-19 h, 21 h, 22-02 h and 04-07 h respectively (Fig. 5 B). The conditions under DD are more or less similar to those of LL(Fig. 6 A, B). While, in fourth instar, the increase in the levels of FAA at $08 \mathrm{~h}, 10 \mathrm{~h}, 12 \mathrm{~h}, 14 \mathrm{~h}, 16 \mathrm{~h}, 18 \mathrm{~h}, 20-22$ $\mathrm{h}, 00 \mathrm{~h}, 02-04 \mathrm{~h}$ and 06-08 $\mathrm{h}$ was accompanied by similar upsurge in protein levels at 09 h, 11 h, 13 h, 15 h, 17 h, 19 h, 22-23 h, $01 \mathrm{~h}, 03-05 \mathrm{~h}$ and at 07-08 h respectively. In the fifth instar, the increase in the levels of FAA at $08 \mathrm{~h}, 10 \mathrm{~h}$, $12 \mathrm{~h}, 14 \mathrm{~h}, 16 \mathrm{~h}, 18 \mathrm{~h}, 20 \mathrm{~h}, 22 \mathrm{~h}, 00 \mathrm{~h}, 02 \mathrm{~h}, 04 \mathrm{~h}$ and 06-08 $\mathrm{h}$ was followed by similar elevations in soluble protein levels at 08-09 h, 09-10 h, 12-13 h, 15 h, 16-17 h, 18 h, 20 h, 22-23 h, 00 h, 02-03 h and 04-05 h respectively. However, the relation between FAA and soluble proteins at $06-08 \mathrm{~h}$ is not clear as the protein levels continuously declined despite an increase in the levels of FAA (Fig. 6 B).

Clearly, the photoperiod modulates protein rhythm of the fat body by mobilizing the free amino acids required for protein synthesis from time to time during the free running time of the rhythm. When the silkworms were reared separately, the LL and dark DD conditions advanced the rhythm by favouring quicker utilization of free amino acids in both the instars, but under LD, the light and dark conditions together delayed the operation of protein rhythm by favouring slow utilisation of the amino acid pool. Probably, because of this reason, the number of protein synthetic cycles is increased from 7 to 9.5 under LLand 8 under DD in fourth instar, and to 7.5 under LLin the fifth instar. This results in advancement of the 24-h free running time of the rhythm by $6.5 \mathrm{~h}$ (6 hours and 30 minutes) under LL and $3 \mathrm{~h}$ under DD in the fourth instar and by $1.6 \mathrm{~h}$ ( 1 hour and 36 minutes) under LL in the fifth instar.

\section{REFERENCES}

Arrese, E. L. and Soulages, J.S. (2010). Insect fat body: Energy metabolism and regulation. Entomology, 55: 207-225.

Chen, W. and You, Q. (2004). Studies on properties of sericin protein of Bombyx mori Part III: Denaturation and deterioration of sericin at high temperature and high humidities. Bull. Ind. Acad. Seri., 8 (1): 23-28.

Ciechanover, A. (2005). Proteolysis from the lysosome to 
ubiquitin and the proteasome. Nat. Rev. M ol. Cell Biol., 6: 79-87.

Colowick, S. P. and Kaplan, N.O. (1957). Methods in Enzymology. Academic Press, New York, 63: 28.

Damiola, F., Le Minh, N., Preitner, N., Kornmann, B., FleuryOlela, F. and Schibler, U. (2000). Restricted feeding uncouples circadian oscillators in peripheral tissues from the central pacemaker in the suprachiasmatic nucleus. Genes Dev., 14 (23): 2950-2961.

David, B.V. and Ananthakrishnan, T.N. (2006). General and Applied Entomology. New Delhi: Tata McGRaw - Hill Publishing Company Ltd., 56-65.

Dolezel, D., Zdechovanova, L., Sauman, I. and Hodkova, M. (2008). Endocrine-dependent expression of circadian clock genes in insects. Cell M ol Life Sci., 65(6): 964 -969.

Durand, B., Drevet, J. and Couble, P. (1992). P25 Gene regulation in Bombyx mori silk gland: two promoter-binding factors have distinct tissue and developmental specificities. Mol. Cell Biol., 12: 5768 - 5777.

Forster, C.H. (2000). Differential control of morning and evening components in the activity rhythm of D rosophila melanogaster-sex-specific differences suggest a different quality of activity. J. Biol. Rhythms, 15 (2): 135-154.

Fukuta, M., Matsuno, K., Hui, C., Nagata, T., Takiya, S., Xu, P.-X., Ueno, K. and Suzuki, Y. (1993). Molecular cloning of a POU domain-containing factor involved in the regulation of the Bombyx sericin-1 gene. J. Boil. Chem., 268: 1947119475.

Gizelak, K. (1995). Control of expression of silk protein genes. Comp. Biochem. Physiol. B: Biochem. M ol. Boil., 110: 671681.

Grima, B., Chelot, B.E., Xia, R. and Rouyer, F. (2004). Morning and evening peaks of activity rely on different clock neurons of the D rosophila brain. Nature, 431:862-868.

Hall, J.D. (2003). Genetics and Molecular Biology of Rhythms in D rosophila and other insects. Academic Press, Amsterdam, pp 286.

Hardin, P.E. (2004). Transcription regulation within the circadian clock: the E- box and beyond. J. Biol. Rhythms, 19: 348-360.

Hou, Y., Xia, Q., Zhao, P., Yong Zou , Y., Liu, H., Guan, J., Gong, J. and Xiang, Z. (2007). Studies on middle and posterior silk glands of silkworm (Bombyx mori) using two-dimensional electrophoresis and mass spectrometry. Insect Biochem. M ol. Biol., 37: 486-496.

Inoue, A., Tanaka, K. and Arisakaffi, F. (2000). Silk fibroin of Bombyx mori is secreted, assembling a high molecular mass elementary unit consisting of H-chain,L-chain, and P25, with a 6:6:1 molar ratio. J. Biol. Chem., 275: 40517-40528.

Ishikawa, E. and Suzuki, Y. (1985). Tissue and stage-specific expression of sericin genes in the middle silk gland of B ombyx mori. Dev. G rowth D iff., 27: 73-82.

Iwai, S., Fukui, Y., Fujiwara, Y. and Takeda, M. (2006). Structure and expressions of two circadian clock genes, period and timeless in the commercial silkmoth, Bombyx mori. J . Insect Physiol., 52(6): 625-637.

Kanyan Xu., Zheng, X. and Seghal, A. (2008). Regulation of feeding and metabolism by neuronal and peripheral clocks in Drosophila. Cell M etabolism, 8: 289-300.

Kenny, N.A. and Saunders, D.S. (1991). Adult locomotor rhythmicity as "hands" of the maternal photoperiodic clock regulating larval diapause in the blowfly, Calliphora vicina. J. Biol. Rhythms, 6: 217-233.

Kimura, K., Oyama, F., Ueda, H., Mizuno,S. and Shimura, K. (1985). Molecular cloning of the fibroin light chain complementary DNA and its use in the study of the expression of the light chain gene in the posterior silk gland of Bombyx mori. Experientia, 41: 1167-1171.

Kita, Y., Shiozawa, M., Jin, W., Majewski, R. R., Besharse, J.C., Greene, A.S. and Jacob, H.J. (2002). Implications of circadian gene expression in kidney, liver and the effects of fasting on pharmacogenomic studies. Pharmacogenetics, 12 (1): 55-65

Koga, M., Ushirogawa, H. and Tomioka, K. (2005). Photoperiodic modulation of circadian rhythms in the cricket, Gryllus bimaculatus. J. Insect P hysiol., 51:219- 230

Krishnaswami, S. (1986). New technology of silkworm rearing. Central Sericultural Research and Training Institute, Mysore, India.

Kyung, H.S., Su, J.J., Young, R.S., Seok, W.K. and Sung, S.H. (2006). Identification of up-regulated proteins in the hemolymph of immunized Bombyx mori larvae.Comp. Biochem. Physiol., D1: 260-266.

Lowry, O.H., Rosenbrough, N.J., Farra, L. and Randall, R.J. (1951). Protein measurement with Folin phenol reagent. J . Biol. Chem., 1933: 265 - 275.

Michaille, J.J., Garel, A. and Prudhomme, J.C. (1989). The expression of five middle silk gland specific genes is territorially regulated during the larval development of Bombyx mori. Insect Biochem., 19: 19-27.

Moore, S. and Stein, W.A. (1954). A modified ninhydrin reagent for the photometric determination of amino acids and related compounds. J. Biol. Chem., 211: 907-913.

Obara, T. and Suzuki, Y. (1988). Temporal and spatial control of silk gene transcription analyzed by nuclear run-on assay. Devl. Biol., 127: 384-391.

Paijo, S. (2010). 'Fat body'. Retrieved December, 202010 from http://insectspedia.blogspot.com/2010/10/fat-body.

Peschel, N., Chen, K.F., Szabo, G. and Stanewsky, R. (2009). Light-dependent interactions between the Drosophila circadian clock factors cryptochrome, jetlag and timeless. Curr. Biol., 19(3): 241-247.

Reppert, S.M. (2006). A colorful model of the circadian clock. Cell, 124: 233-236.

Sailaja, B. and Sivaprasad, S. (2010 a). Photoperiodic modulation of circadian rhythms in the silk gland protein profiles of Bombyx mori and its influence on the silk productivity and quality. J. Appl. \& Nat. Sci., 2(1): 48-56.

Sailaja, B. and Sivaprasad, S. (2010 b). Photoperiodic modulation of circadian protein rhythm in the silk gland of Bombyx mori during fourth instar development. Bioscan., 5 (2): 177- 183

Sehadova, H., Markova, E.P., Sehnal, F. and Takeda, M.(2004). Distribution of circadian clock related proteins in the cephalic nervous system of the silkworm, Bombyx mori. J ournal of Biological Rhythms, 19:466-482.

Scott, R.C., Schuldiner, O. and Neufeld, T.P. (2004). Role and regulation of starvation-induced autophagy in the D rosophila fat body. Dev. Cell,7;167-178.

Shafer, T.O., Levine, J.D., Truman, J.W. and Hall, J.C. (2004). 
Flies by night: Effects of changing day length on D rosophila's circadian clock. C ur r. Biol.,14 (5): 424-432.

Sharma, V. K. (2003). Adaptive significance of circadian clocks. Chronobiol. Int., (20):901-919.

Shimizu, I., Kawai, Y., Tainguchi, M. and Aoki, S. (2001). Circadian rhythm and cDNA cloning of the clock gene period in the honeybee A pis cer ana japonica. Zoological Science, 18: 778-789.

Stokkan, K.A., Yamazaki, S., Tei, H., Sakaki, Y. and Menaker, M. (2001). Entrainment of the circadian clock in the liver by feeding. Science, 291(5503): 490-493.

Stoleru, D., Peng, Y., Agosto, J. and Rosbash, M. (2004). Coupled oscillators control morning and evening locomotor behaviour of D rosophila. Nature, 431: 862-868.
Syrova, Z., Dolezel, D., Saumann, I. and Hodkova, M. (2003). Photoperiodic regulation of diapause in linden bugs: Are period and Clock genes involved? Cell. Mol. Life Sci., 60: 2510-2515.

Takasu, Y., Yamada, H., Saito, H. and Tsubouchi, K. (2005). Characterization of Bombyx mori Sericins by the Partial Amino Acid Sequences. J. Insect Biotechnology and Sericology, 74: 103-109.

Yamaoka, K., Hoshino, M. and Hirai, T.(1971). Role of sensory hairs on the anal papillae in oviposition behaviour of B ombyx mori. J. Insect Physiol., 47: 2327-2336.

Zhang, P. B., Aso, Y.K., Yamamoto, Banno, Y., Wang, Y.Q., Tsuchida, K.Y., Kawaguchi and Fujii, H. (2006). Proteome analysis of silk gland proteins from the silkworm, Bombyx mori. Proteomics, 6: 2586-2599. 